Atmos. Chem. Phys., 10, 9487-9503, 2010

www.atmos-chem-phys.net/10/9487/2010/

doi:10.5194/acp-10-9487-2010

(C) Author(s) 2010. CC Attribution 3.0 License.

\title{
Occurrence of gas phase ammonia in the area of Beijing (China)
}

\author{
A. Ianniello ${ }^{1}$, F. Spataro ${ }^{1}$, G. Esposito ${ }^{1}$, I. Allegrini ${ }^{1}$, E. Rantica ${ }^{1}$, M. P. Ancora ${ }^{1}$, M. Hu ${ }^{2}$, and T. Zhu ${ }^{2}$ \\ ${ }^{1}$ CNR - Institute of Atmospheric Pollution Research, Via Salaria Km 29.3, CP10, 00015 Monterotondo S., Rome, Italy \\ ${ }^{2}$ State Key Joint Laboratory for Environmental Simulation and Pollution Control, College of Environmental Sciences \\ and Engineering, Peking University, Beijing, China
}

Received: 6 May 2010 - Published in Atmos. Chem. Phys. Discuss.: 9 June 2010

Revised: 10 September 2010 - Accepted: 26 September 2010 - Published: 7 October 2010

\begin{abstract}
The atmospheric concentrations of gaseous ammonia have been measured during two field campaigns in the winter and in the summer of 2007 at Beijing (China). These measurements were carried out by means of diffusion annular denuders coated with phosphorous acid. The results were discussed from the standpoint of temporal and diurnal variations and meteorological effects. The daily average $\mathrm{NH}_{3}$ concentrations were in the range of $0.20-44.38 \mu \mathrm{g} / \mathrm{m}^{3}$ and showed regular temporal variations with higher concentrations during summer and with lower during winter. The temporal trends seemed to be largely affected by air temperature because of agricultural sources. No diurnal variability was observed for gaseous $\mathrm{NH}_{3}$ levels in both winter and summer seasons. The highest ammonia value of $105.67 \mu \mathrm{g} / \mathrm{m}^{3}$ was measured in the early morning during the summer period when stable atmospheric conditions occurred. The diurnal winter and summer trends of ammonia showed a weak dependence on the air temperature and they were affected nearly by wind direction suggesting regional and local source influences. Ammonia was also correlated with the atmospheric mixing in the boundary layer, and, with $\mathrm{NO}_{\mathrm{x}}, \mathrm{CO}$ and $\mathrm{PM}_{2.5}$ air concentrations supporting the hypothesis that the traffic may be also an important source of ammonia in Beijing.
\end{abstract}

\section{Introduction}

Gaseous ammonia $\left(\mathrm{NH}_{3}\right)$ is the third most abundant nitrogen containing compound and is the primary alkaline trace gas in the atmosphere. The importance of ammonia in urban areas is related to its role as a precursor for secondary aerosols

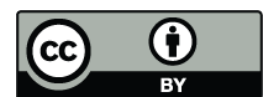

Correspondence to: A. Ianniello (ianniello@iia.cnr.it)
(Erisman and Schaap, 2004). It neutralizes atmospheric acids such as nitric acid $\left(\mathrm{HNO}_{3}\right)$, hydrochloric acid $(\mathrm{HCl})$ and sulphuric acid $\left(\mathrm{H}_{2} \mathrm{SO}_{4}\right)$, formed by oxidation of nitrogen oxides $\left(\mathrm{NO}_{\mathrm{x}}\right)$ and sulphur dioxide $\left(\mathrm{SO}_{2}\right)$, respectively (Krupa, 2003), thereby affecting the acidity of cloud water and aerosols (Heeb et al., 2006; Roelle and Aneja, 2002). The reaction rates for $\mathrm{NH}_{3}$ depend on the acid concentration, humidity and temperature. The main chemical sink for ammonia in the atmosphere is the reaction with $\mathrm{H}_{2} \mathrm{SO}_{4}$, yielding ammonium sulphate $\left[\left(\mathrm{NH}_{4}\right)_{2} \mathrm{SO}_{4}\right]$ and ammonium bisulphate $\left[\mathrm{NH}_{4} \mathrm{HSO}_{4}\right]$ salts. Reactions with $\mathrm{HNO}_{3}$ and $\mathrm{HCl}$ yield ammonium nitrate $\left(\mathrm{NH}_{4} \mathrm{NO}_{3}\right)$ and ammonium chloride $\left(\mathrm{NH}_{4} \mathrm{Cl}\right)$ salts in particulate phase. These $\mathrm{NH}_{4}^{+}$aerosols contribute significantly to fine particle mass (size $<2.5 \mu \mathrm{m}$ ) and have implications for human health (Brunekreef and Holgate, 2002). They limit atmospheric visibility and alter global radiation budgets (Horvat, 1992; Sutton et al., 1994).

The most recent consideration for $\mathrm{NH}_{3}$ emissions on the global scale is linked to climate change based on its ability to form $\mathrm{PM}_{2.5}$, specifically ammonium sulphates. These aerosols can possibly increase the earth's albedo. Particles can either backscatter UV and visible radiation directly, reducing the amount that reaches the earth's surface, or indirectly by increasing cloud cover due to increased numbers of cloud condensation nuclei, particles that give rise to cloud formation (Sutton et al., 2004). $\mathrm{NH}_{3}$ has a relatively short residence time of about 1 to $5 \mathrm{~d}$. When airborne, it is either readily converted to ammonium aerosols, due to their extended lifetime (about 1-15d), these particles may be transported far from the pollutant sources (Aneja et al., 2001; Krupa, 2003) causing effects to sensitive ecosystems with consequent changes in soil, plant and animal communities (Sutton et al., 1993; Fangmeier et al., 1994). In fact, after deposition, $\mathrm{NH}_{4}^{+}$aerosols can contribute to acidification and eutrophication of these habitats. Thus, since $\mathrm{NH}_{3}$ is either readily converted to $\mathrm{NH}_{4}^{+}$or subjected to dry deposition, high

Published by Copernicus Publications on behalf of the European Geosciences Union. 
concentrations are expected only close to the surface and near to emission sources (Ferm, 1998). Although the main source of atmospheric ammonia is agriculture, other sources include industries, landfills, household products, biomass burning, motor vehicles, and wild animals.

Only few studies on ammonia emissions in China are available. The total $\mathrm{NH}_{3}$ emission from China are estimated to be about two to three times higher than European and US emissions over the period of 1990 to 2005 (Klimont, 2001; Zhao and Wang, 1994; EMEP, 2009; USEPA, 2009; Reis et al., 2009). About $80 \%$ of $\mathrm{NH}_{3}$ emission in China is from agriculture. In China, the biggest contributors are livestock (which contributes about 30\%-60\%) and the application of nitrogenous fertilizer (which contributes about 17\%-47\%), followed by $20 \%$ for energy, $1 \%$ for poultry and $2.5 \%$ for human beings (Zhao and Wang, 1994; Oliver et al., 1998; Streets et al., 2003; He et al., 2007). However, estimations of $\mathrm{NH}_{3}$ emissions have only been started relatively recently and still contain many uncertainties (Bouwman et al., 1997; Battye et al., 2003; Goebes et al., 2003). The characteristics of agricultural sources determine the temporal and spatial $\mathrm{NH}_{3}$ distribution in many locations. The ammonia concentration in northern cities of China is relatively high during the spring and summer period due to farming, while in southern cities no obvious seasonal variation occurs because farmland is extended during all four seasons.

In addition to $\mathrm{NH}_{3}$ emissions, the relative humidity, the temperature, and the insulation are also important factors influencing the formation, temporal and spatial distribution of secondary particles. According to studies of the ammonia level in China, in Beijing, some research has shown that the concentration of secondary particles are higher in the winter probably due to the high $\mathrm{SO}_{2}$ emissions and low wind speed, which aid the formation of $\mathrm{SO}_{4}^{2-}$. Another study has shown that summer has the highest secondary particle concentration, because of the large $\mathrm{NH}_{3}$ emissions and sufficient temperature and humidity to ensure the oxidation of $\mathrm{SO}_{2}$ to $\mathrm{SO}_{4}^{2-}$ (He et al., 2001, 2002).

The contribution of vehicles to non-agricultural $\mathrm{NH}_{3}$ emissions has been considered to be negligible up to 1995 (Sutton et al., 1995). Recent studies, however, show that ammonia concentration in urban environments has also increased due to over-reduction of nitrogen oxide compounds in catalytic converters in automobiles exhaust and industrial and power station emission abatement technology (Sutton et al., 2000). From measurements in a roadway tunnel, Fraser and Cass (1998) concluded that the contribution of motor vehicle emissions had risen from $2 \%$ to $15 \%$ of the total ammonia emission in the Los Angeles area since the introduction of catalysts. Road side measurements in the UK, in the USA and Europe have shown strong links between ammonia emissions and traffic (Kean et al., 2000; Kirchner et al., 2002; Perrino et al., 2002; Cape et al., 2004). Perrino et al. (2002) found a close link between ammonia and $\mathrm{CO}$ emissions in a series of experiments conducted in Rome. These results in- dicated that petrol-engine vehicles constitute a major source of urban ammonia.

There have been a number of studies of urban ammonia concentrations in recent years. Long-term measurements have shown strong daily and seasonal variations in ammonia concentrations which depend mainly on temperature, relative humidity $(\mathrm{RH})$, rainfall, and wind speed (Yamamoto et al., 1988, 1995; D. S. Lee et al., 1999; Bari et al., 2003; Vogt et al., 2005). Bimodal diurnal variations in $\mathrm{NH}_{3}$ concentrations with peaks occurring during periods of peak traffic have been observed in some studies (Kirchner et al., 2002; Perrino et al., 2002; Li et al., 2006), confirming vehicles as a significant source of $\mathrm{NH}_{3}$. Data about ammonia concentrations in the urban areas of China, especially of Beijing, are very rare. Median ammonia concentrations ranged from 20 to $1 \mathrm{ppb}$ on a monthly basis according to measurements carried out in Asia (Carmichael et al., 2003). Yao et al. (2003) measured $\mathrm{NH}_{3}$ concentrations in Beijing in summer 2001 and spring 2002. The concentrations were found from 4.6 to $42.4 \mu \mathrm{g} / \mathrm{m}^{3}$ with the highest concentration detected in July. Recent realtime measurements of ammonia were conducted in the Pearl River Delta, China, from 4 October to 4 November 2004 (Hu et al., 2008). During this study the average concentration of $\mathrm{NH}_{3}$ was $7.3 \mu \mathrm{g} / \mathrm{m}^{3}$.

With increasing concern over the potential environmental damage caused by atmospheric transport and subsequent deposition of $\mathrm{NH}_{3}$, it is very important to have reliable methods to accurately monitor its pollution level and emission pattern. Such information may then be used effectively to develop potential abatement strategies for $\mathrm{NH}_{3}$.

Sampling of $\mathrm{NH}_{3}$ is difficult because it is easily adsorbed on surfaces and is difficult to separate and discriminate from volatile ammonium salts. Annular denuder techniques are considered to be able to overcome these critical sources of error. In general, such systems are designed with a vertically positioned denuder tube to eliminate the sedimentation of particles (Possanzini et al., 1983; Allegrini et al., 1987, 1999; Febo et al., 1989; Perrino et al., 1990). This sampling technique is able to accurately determine gaseous ammonia and particulate ammonium without disturbing the partition existing in the atmosphere at the time of the sampling and without mutual interferent (Perrino et al., 1999, 2002).

We report in this paper the results of some measurements of ammonia concentrations carried out during 2007 in Beijing, China, by using annular denuder based methods. The data are analyzed and presented here to investigate the daily and seasonal variations in ammonia concentrations and also to examine the contribution of traffic to ammonia levels in Beijing. The study is a part of a Sino-Italian collaboration project (Blue Sky of Beijing: Research on Regional Air Pollution Project) and also part of the international collaborative research CAREBEIJING (Campaigns of Air Quality Research in Beijing and Surrounding Region). 


\section{Experimental}

Measurements were carried out in the campus of Peking University (PKU), located at North of Beijing $\left(39^{\circ} 59^{\prime} 23^{\prime \prime} \mathrm{N}\right.$, $116^{\circ} 18^{\prime} 19^{\prime \prime} \mathrm{E}$ ), not very far from Olympic sites in winter, from 23 January to 14 February 2007, and in summer, from 2 to 31 August 2007. The atmospheric ammonia concentrations were determined by means annular diffusion denuders coated with a solution of $1 \%$ phosphorous acid in 1:9 water and ethanol (Perrino and Gherardi, 1999) on a 24-h basis starting at midnight. The air samples on a 2 -h basis (intensive measurements) were also carried out on 9-10 February during the winter period and on 13-15 and 17-21 August during the summer period. Problems occurred on 9 February between 10:00 and 12:00 in the morning and on $19 \mathrm{Au}-$ gust between 22:00 and 00:00, thus data from these events were not considered. The annular denuder sampling method and the analytical procedures were described in several past works (Possanzini et al., 1983; Allegrini et al., 1987, 1999; Febo et al., 1989; Perrino et al., 1990, 2001a; Beine et al., 2001; Ianniello et al., 2002).

After collection, the denuders and filters were extracted and samples were analyzed within 24-h by using Ion Chromatography (IC) (Dionex DX 120 connected with autosampler DX AS50 for anions and DX ICS90 connected with autosampler DX AS40 for cations).

The individual annular denuders placed at PKU site are made of Pyrex glass, $21 \mathrm{~cm}$ in length, 3.0 and $3.3 \mathrm{~cm}$ in annulus diameter. The sampling flow rate was $15 \mathrm{l} / \mathrm{min}$. The sampling volume was about $23.10 \mathrm{~m}^{3}$ for a 24-h sampling period. In these operative conditions the collection efficiency for ammonia was higher than $99 \%$ and the detection limit, based on three times the standard deviations of field blanks, was $0.06 \mu \mathrm{g} / \mathrm{m}^{3}$ for a sampling time of $24 \mathrm{~h}$. Precision of these measurements was $1.22 \%$.

Although the focus of this paper is on atmospheric ammonia, the denuder system also sampled other gaseous as well as particulate species. In fact, the denuder line consisted of two sodium fluoride coated denuders for the simultaneous collection of $\mathrm{HCl}$ and $\mathrm{HNO}_{3}$, followed by two sodium carbonate coated denuders for the collection of $\mathrm{HONO}$ and $\mathrm{SO}_{2}$. A fifth denuder in the line is coated with phosphorous acid for the collection of $\mathrm{NH}_{3}$. Downstream of the denuder train a cyclone collects coarse particles $(>2.5 \mu \mathrm{m}$ of cut size at flow rate of $15 \mathrm{l} / \mathrm{min}$ ), while fine particles $(<2.5 \mu \mathrm{m}$ at flow rate of $15 \mathrm{l} / \mathrm{min}$ ) are collected on a filter pack set in series. The filter pack consisted of one Teflon filter, one Nylon filter, and one paper filter impregnated with phosphorous acid. The last two back-up filters were used to measure the volatile ammonium salts indicated with term of evolved salts. The particulate chloride, nitrate, sulphate, sodium, ammonium, potassium, magnesium and calcium coarse and fine fractions were measured and analyzed.

Information about the mixing properties of the lower boundary layer was obtained by means of a Stability Monitor
(OPSIS SM200) during the summer period. This instrument collects atmospheric particles and determines their short life radioactivity due to Radon decay products, providing 1-h interval radioactivity data. From the study of the temporal trend of natural radioactivity and of its time derivative one can gather important information about the mixing properties of the lower atmosphere and about its ability to dilute atmospheric pollutants (Perrino et al., 2001b).

\section{Results and discussion}

\subsection{Temporal variation}

The temporal patterns of gaseous ammonia determined by means of the diffusion lines in the winter and summer periods are reported in Fig. 1. Table 1 shows summary statistics for $\mathrm{NH}_{3}$ concentrations $\left(\mu \mathrm{g} / \mathrm{m}^{3}\right)$ and air temperature $(T)$ values $\left({ }^{\circ} \mathrm{C}\right)$ measured during the two sampling periods in Beijing.

The temporal variations are evaluated applying the paired $t$-test to determine the significance at the 0.05 level ( $p \leq$ 0.05 ) of differences among the mean of components by examining the amount of variation between the samples. $\mathrm{NH}_{3}$ exhibited a distinct and significant $(p<0.001)$ temporal variation with higher concentrations in summer than in winter (Fig. 1). This difference in $\mathrm{NH}_{3}$ concentrations has also been observed by other papers and is in agreement with the temperature dependence of $\mathrm{NH}_{3}$ emissions from animal waste, natural and fertilized soils, and vegetations (Langford and Fehsenfeld, 1992; Langford et al., 1992; Yamamoto et al., 1995; Asman et al., 1998; Lefer et al., 1999; Aneja et al., 2000; Robarge et al., 2002; Pryor et al., 2001), which are at low values during winter. The characteristics of these sources determine the temporal and spatial $\mathrm{NH}_{3}$ distribution. Source strength and removal efficiency can explain the seasonal variations of $\mathrm{NH}_{3}$ concentrations. In summer, high temperatures will favor ammonia volatilization from urea and/or ammonium bicarbonate applied to crops. High temperatures in summer will also favour $\mathrm{NH}_{3}$ emission from other sources, such as animal housing, landfill, laystalls and farmers' toilets, animal manure, natural and fertilized soils, and vegetation. Therefore, atmospheric ammonia concentrations were highest in summer at Beijing site. Thus, in agreement with past studies, higher ammonia emissions occurred when air temperature increased, suggesting intense local sources for $\mathrm{NH}_{3}$ during the summer season at Beijing.

\subsection{Diurnal variation}

\subsubsection{Winter}

During the intensive measurements at PKU in Beijing, the wind speed reached a maximum value of $8.8 \mathrm{~m} / \mathrm{s}$ on 9 February at 14:00 and the wind blew mainly from northwest, southwest and southeast (Fig. 2). The air temperature increased at 08:00 reaching maxima values between 12:00 and 


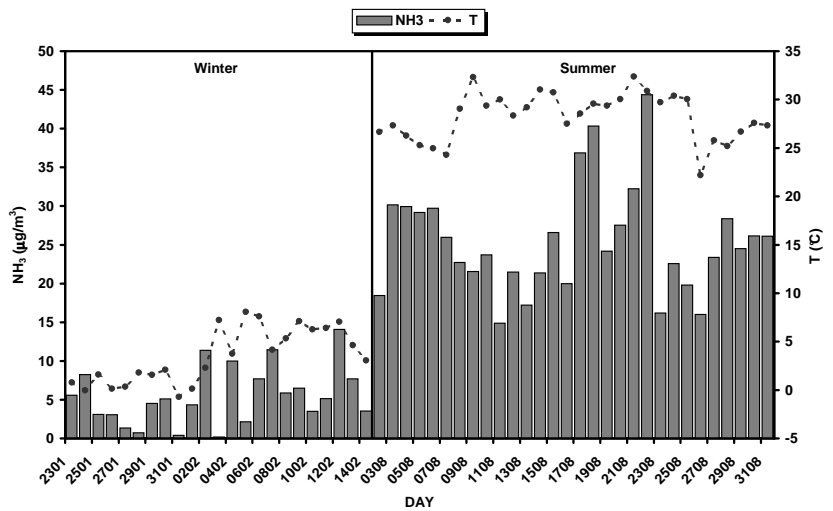

Fig. 1. Temporal trend of ammonia during the winter and summer campaigns at Beijing.

14:00 of about $13.98^{\circ} \mathrm{C}$. In addition, the solar radiation also reached higher values of about $13 \mathrm{~W} / \mathrm{m}^{2}$ on $9-10$ February at 13:00 while the relative humidity decreased during all the intensive measurements starting on 9 February at 06:00 in the morning.

The mean level of ammonia within \pm one standard deviation for the entire data $(N=23)$ was $5.22 \pm 3.75 \mu \mathrm{g} / \mathrm{m}^{3}$. Ammonia hardly showed any diurnal variation in winter period (Fig. 3), in agreement with past studies (Lefer et al., 1999; Danalatos and Glavas, 1999; Walker et al., 2004). Data were grouped into sunrise (between 06:00 and 18:00) and sunset (between 18:00 and 06:00) times. On applying $t$ test to day and night samples, diurnal variation was not found to be statistically significant $(p=0.18)$. Having a short lifetime of about one day, ammonia would be expected to peak in the middle of the day as higher emissions are expected in that part of the day. This occurred on 9 and 10 February between 08:00 and 10:00 but higher ammonia emissions occurred also in other periods of the day, as measured after sunset and night, during the intensive measurements. Night time high ammonia levels can be attributed to stable atmosphere during the night time (Cadle et al., 1982; Perrino et al., 2002) while the higher mixing height in the middle of the day balanced the higher ammonia emissions resulting in little diurnal variation (Singh et al., 2001).

Since $\mathrm{NH}_{3}$ is either readily converted to $\mathrm{NH}_{4}^{+}$or subjected to dry deposition, high concentrations are found only close to the surface and near to emission sources (Ferm, 1998; Krupa, 2003). Thus, $\mathrm{NH}_{3}$ concentrations might be generally lower at higher wind speeds because of turbulent diffusion. Previous studies have reported an inverse relationship between ground-level concentrations of trace gases, such as ammonia, and wind speed (Katsoulis, 1996; D. S. Lee et al., 1999; Robarge et al., 2002). This inverse relationship between natural-log transformed $\mathrm{NH}_{3}$ concentrations and wind speeds (Robarge et al., 2002) did not occur at significant level $\left(R^{2}=0.18, p<0.001\right)$ considering concentrations measured
Table 1. Statistics for $\mathrm{NH}_{3}$ and $T$ during the winter and summer campaigns at PKU site.

\begin{tabular}{lrrrr}
\hline & \multicolumn{2}{c}{ Winter } & \multicolumn{2}{c}{ Summer } \\
& $\mathrm{NH}_{3}\left(\mu \mathrm{g} / \mathrm{m}^{3}\right)$ & $T\left({ }^{\circ} \mathrm{C}\right)$ & $\mathrm{NH}_{3}\left(\mu \mathrm{g} / \mathrm{m}^{3}\right)$ & $T\left({ }^{\circ} \mathrm{C}\right)$ \\
\hline$N$ of cases & 23 & 23 & 30 & 30 \\
Minimum & 0.20 & -0.71 & 14.87 & 22.19 \\
Maximum & 14.08 & 8.06 & 44.38 & 32.37 \\
Median & 5.12 & 3.05 & 24.33 & 28.80 \\
Mean & 5.47 & 3.51 & 25.39 & 28.27 \\
Standard Dev & 3.75 & 2.88 & 6.91 & 2.46 \\
\hline
\end{tabular}

only on 9 February 2007. In addition, highest $\mathrm{NH}_{3}$ concentrations were also associated with low wind speeds during this day.

Besides, the diurnal pattern of ammonia did not show a clear and well-defined temperature and humidity dependence during the winter field campaign, as observed elsewhere (Langford and Fehsenfeld, 1992; Yamamoto et al., 1995; Burkhardt et al., 1998; Horvath and Sutton, 1998; Pryor et al., 2001; Olszyna et al., 2005; Vogt et al., 2005). This may reflect the influence of other factors, such as local sources and wind direction, in determining ambient concentrations of $\mathrm{NH}_{3}$ (Burkhardt et al., 1998; Huber and Kreutzer, 2002; Vogt et al., 2005). However, a weak but significant linear correlation $\left(R^{2}=0.32, p=0.01\right)$ can be obtained between $\mathrm{NH}_{3}$ and air temperature considering ammonia concentrations measured from 12:00 on 9 February, when the air temperature reached maxima values (12:00-16:00 on two days), to the end of intensive measurements on 10 February. This weak temperature dependence of $\mathrm{NH}_{3}$ reflects the small influence of the emission sources from agricultural activity which increase as the temperature rises. Ammonia emissions from animal manure, natural and fertilized soils, and vegetation will increase with temperature owing to the temperature dependency of aqueous-phase partitioning between $\mathrm{NH}_{3}$ and $\mathrm{NH}_{4}^{+}$in these systems, as well as the atmospheric equilibrium between $\mathrm{NH}_{3}$ with volatile ammonium nitrate. In fact, during this period the winds came principally from northwest direction (73\%) (Fig. 2b) coinciding with the direction of agricultural areas such as Xibeiwang and Changping District which are located at the northwest suburb of sampling site (Shen et al., 2009; Zhang et al., 2010). The temperature dependence of $\mathrm{NH}_{3}$ disappeared from 00:00 to 12:00 on 9 February with prevailing winds from southeast and southwest (60\%) (Fig. 2a) and lower temperatures. This different behaviour may be explained from prevalence of local sources, such as traffic emissions, in determining the atmospheric $\mathrm{NH}_{3}$ concentrations during this period.

While agriculture is the main source of atmospheric ammonia in Beijing, the contribution of vehicles, equipped with catalytic converters, especially since the introduction of three-way-catalysts, to non-agricultural $\mathrm{NH}_{3}$ emissions 


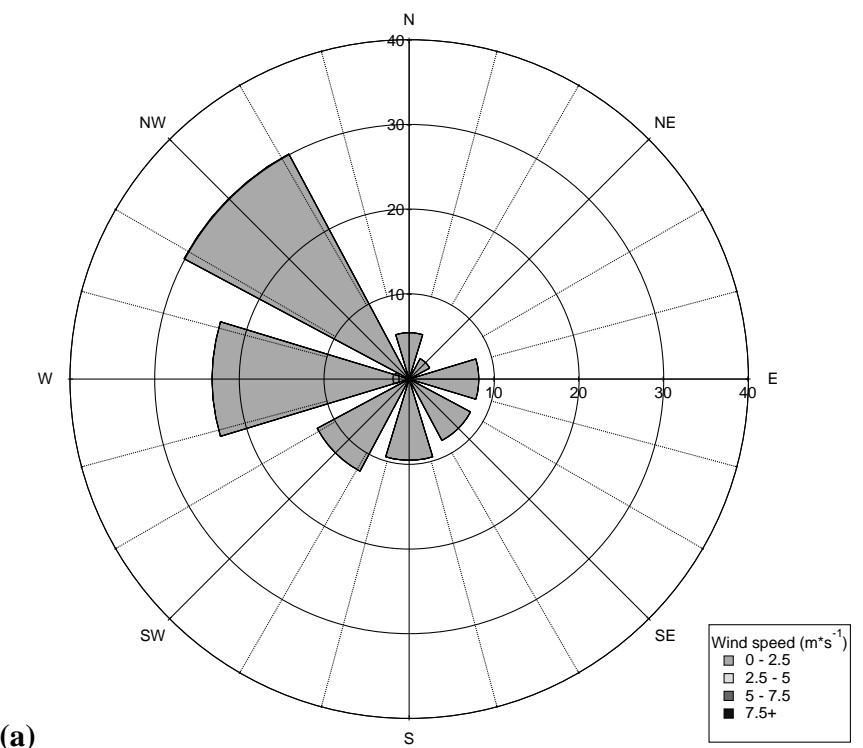

(a)

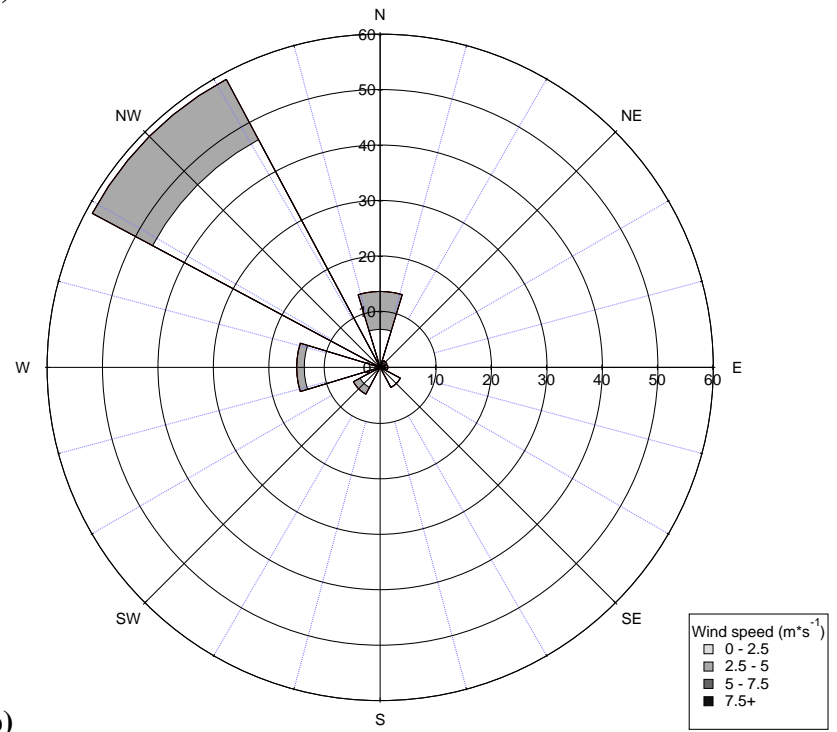

Fig. 2. Wind plots showing the frequency distributions of wind directions and speeds (grey scale) of the intensive winter measurements for two days: on 9 February (a) and 10 February (b). The radius axis represents the occurrence from $0 \%$ to $40 \%$ and from $0 \%$ to $60 \%$, respectively.

has recently been considered and might be the most important factor influencing ammonia concentrations at urban locations and near roads (Sutton et al., 2000; Kean et al., 2000; Heeb et al., 2008). Also Beijing city is configured such that it is served by several ring roads with heavy traffic (Fig. 4). Figure 4 shows Beijing city, measurement site and surrounding regions, where are the major $\mathrm{NH}_{3}$ emission sources. Therefore, in order to examine the contribution of traffic to $\mathrm{NH}_{3}$ concentrations it may be useful to compare the ammonia concentrations with those of primary non-reactive pollutants mainly emitted by motor-vehicle exhausts (Per- rino et al., 2002), such as nitrogen oxides $\left(\mathrm{NO}_{\mathrm{x}}\right)$ and carbon monoxide (CO), throughout this winter period. The time series of $\mathrm{NH}_{3}, \mathrm{NO}_{\mathrm{x}}, \mathrm{CO}$, wind direction, wind speed, temperature and relative humidity are shown in Fig. 3. Both $\mathrm{CO}$ and $\mathrm{NO}_{\mathrm{x}}$ are commonly used as traffic emission indicators (He et al., 2002; Meng et al., 2008; Chak and Yao, 2008). Hao et al. (2005) estimated that the emissions in Beijing from vehicles, power plants, and industries in 1999 accounted for $35 \%$, $27 \%$ and $26 \%$ in the total local $\mathrm{NO}_{\mathrm{x}}$ emissions, respectively. They found that $74 \%$ of the ground $\mathrm{NO}_{\mathrm{x}}$ was due to vehicular emissions while power plants and industrial sources only contributed $2 \%$ and 13\%, respectively. In addition, in Beijing and Guangzhou, automobile pollution contribution in terms of $\mathrm{CO}$ was estimated to be more than $80 \%$ with two peak vehicle pollution levels occurring during each day, one from about 08:00-10:00 and the other from 15:00-17:00 during the rush hours (Hao et al., 2000).

$\mathrm{NO}_{\mathrm{x}}$ peaks were observed between 08:00 and 12:00 on 9 February (Fig. 3). Wind from the southeast and southwest was dominant at the sampling site on 9 February, while wind from the northwest dominated on 10 February. Wind speeds on 9 and 10 February ranged from 0.02 to $8.85 \mathrm{~m} / \mathrm{s}$ and from 0.06 to $4.10 \mathrm{~m} / \mathrm{s}$, respectively. However, on 9 February the overall $\mathrm{NO}_{\mathrm{x}}$ level was significantly higher (from 11.60 to $243.55 \mathrm{ppb}$ ) than that on 10 February (from 5.85 to $73.40 \mathrm{ppb})$. The locations of the major $\mathrm{NO}_{\mathrm{x}}$ sources, including local roads (motor vehicles), expressways, and power plants, which are six and principally coal-fired in Beijing, are located from the east to the southwest of the sampling site (Lee et al., 2009). Thus, the weak wind speeds between 00:00 and 12:00 $(0.02-1.53 \mathrm{~m} / \mathrm{s})$ and southeasterly and southwesterly wind directions on 9 February, in combination with the locations of the sources of $\mathrm{NO}_{\mathrm{x}}$ emissions, resulted in higher $\mathrm{NO}_{\mathrm{x}}$ concentrations between 08:00 and 12:00 due to emissions from Friday traffic during this daytime. Instead, the high wind speeds $(0.30-3.83 \mathrm{~m} / \mathrm{s})$ and northwesterly wind direction on 10 February resulted in lower $\mathrm{NO}_{x}$ concentrations at the sampling site. In fact, $\mathrm{NO}_{\mathrm{x}}$ concentration was about $31.55 \mathrm{ppb}$ at 08:00 on 10 February, which is about eight times lower than that recorded at the same time of day on 9 February ( $243.55 \mathrm{ppb})$. These differences in $\mathrm{NO}_{\mathrm{x}}$ concentrations between two days might reflect the characteristic of Friday traffic (on 9 February) and the wind conditions, which were marked by low winds and prevailing wind direction from the center of Beijing toward the sampling site (60\% from southeast and southwest). The scatter plot of $\mathrm{NH}_{3}$ concentrations vs. $\mathrm{NO}_{\mathrm{x}}$ concentrations during these two days (Fig. 5) showed a good and significant (at the $99.9 \%$ confidence level, $p<0.001$ ) linear correlation of the two data sets $\left(R^{2}=0.65\right)$, supporting the hypothesis that the traffic is also an important source of $\mathrm{NH}_{3}$ in this season within the city. However, for the $\mathrm{NH}_{3}$ and $\mathrm{NO}_{\mathrm{x}}$ data, the best correlation $\left(R^{2}=0.80, p<0.001\right)$ was obtained considering concentrations measured on 9 February during the formation of the highest peaks of ammonia and nitrogen oxides due 


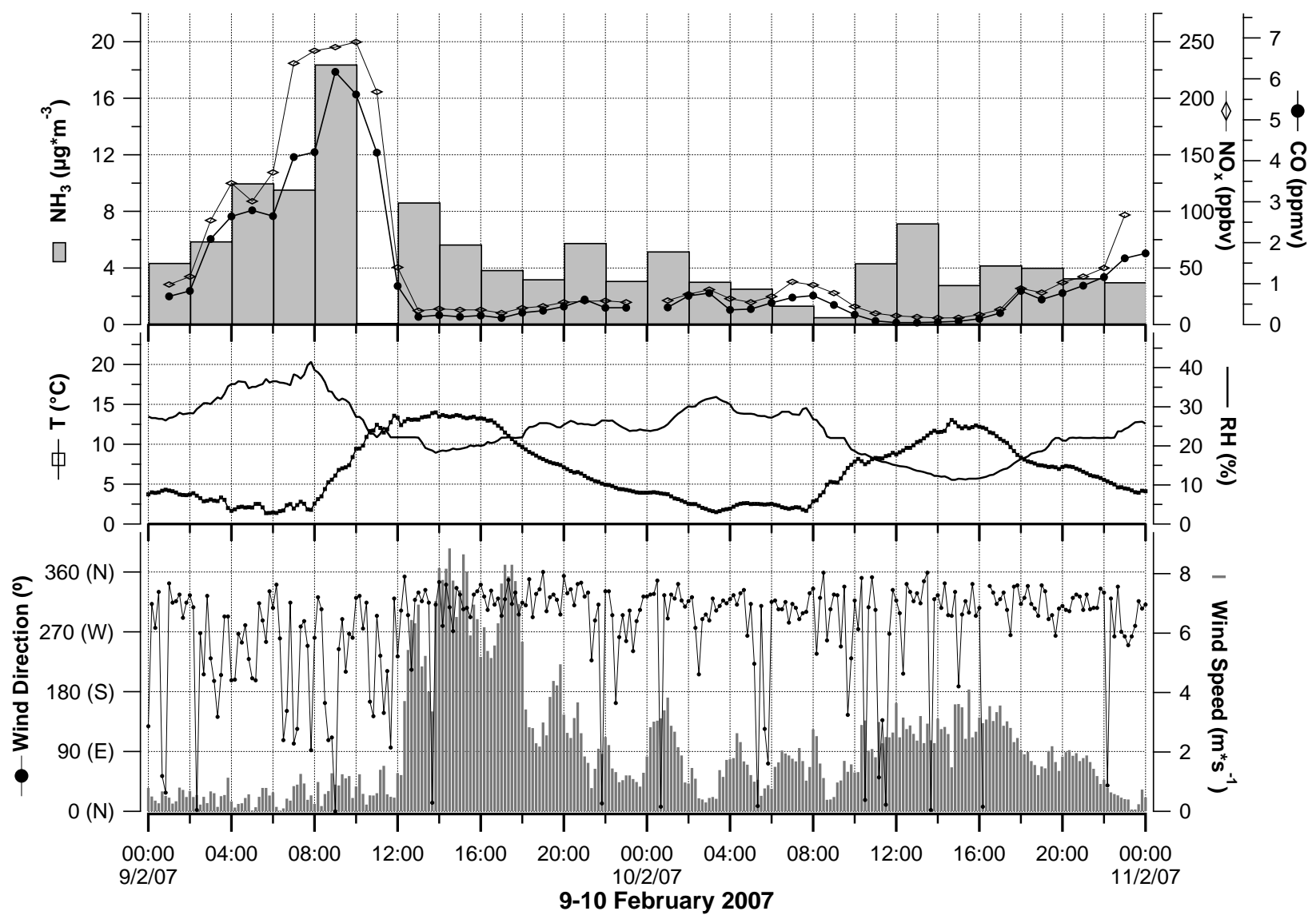

Fig. 3. Diurnal trends of $\mathrm{NH}_{3}, \mathrm{NO}_{\mathrm{x}}, \mathrm{CO}$, temperature $(T)$, relative humidity $(\mathrm{RH})$, wind speed and direction during the intensive winter measurements.

to rush-hour traffic. However, the amount of scatter about these regression lines indicates that other ammonia sources not linked to $\mathrm{NO}_{\mathrm{x}}$ are also significant. In a city centre location, these will largely be human sources (Whitehead et al., 2007). In contrast, the correlation between $\mathrm{NH}_{3}$ and $\mathrm{NO}_{\mathrm{x}}$ did not occur considering concentrations measured only on 10 February during high wind speeds and northwesterly wind direction from where no major sources of $\mathrm{NO}_{\mathrm{x}}$ are located. These results, in combination with weak temperature dipendence of $\mathrm{NH}_{3}$ during on 10 February, as said above, suggest that $\mathrm{NH}_{3}$ concentrations were influenced mainly by non traffic-sources such as agricultural emissions.

In addition, the same findings were also observed comparing the ammonia concentrations with those of $\mathrm{CO}$ (Fig. 3). CO peaks were observed between 08:00 and 10:00 on 9 February. However, on 9 February the overall CO level was significantly higher (from 0.16 to $6.17 \mathrm{ppm}$ ) than that on 10 February (from 0.05 to $1.62 \mathrm{ppm}$ ) due to time period and wind conditions, as said above for $\mathrm{NO}_{\mathrm{x}}$. The scatter plot of $\mathrm{NH}_{3}$ concentration vs. $\mathrm{CO}$ concentrations during these two days (Fig. 6) showed a good and significant (at the 99.9\% confidence level, $p<0.001)$ linear correlation of the two data sets $\left(R^{2}=0.67\right)$, supporting the hypothesis that the traf- fic is also an important source of $\mathrm{NH}_{3}$ in this season within the city. However, for the $\mathrm{NH}_{3}$ and $\mathrm{CO}$ data, the best correlation $\left(R^{2}=0.84, p<0.001\right)$ was obtained considering concentrations measured on 9 February during the formation of the highest peaks of ammonia and carbon monoxide due to rush-hour traffic. In contrast, the correlation between $\mathrm{NH}_{3}$ and $\mathrm{CO}$ did not occur considering concentrations measured only on 10 February during high wind speeds and northwesterly wind direction. These results, in combination with weak temperature dipendence of $\mathrm{NH}_{3}$ during on 10 February, further show that $\mathrm{NH}_{3}$ concentrations were influenced mainly by non traffic-sources such as agricultural emissions.

Thus, the presence of local sources, such as traffic emissions, on 9 February and non-traffic sources on 10 February probably explains why the temperature did not determine $\mathrm{NH}_{3}$ concentrations in Beijing and why a diurnal cycle of $\mathrm{NH}_{3}$ has not been observed because it showed high variability due to variation in emissions during two days of winter intensive measurements.

To help interpret further in general terms the source regions affecting the sampled ammonia and, thus, to identify the origin and transport pathway of large-scale air masses, 24-h backward trajectories arriving at the sampling 

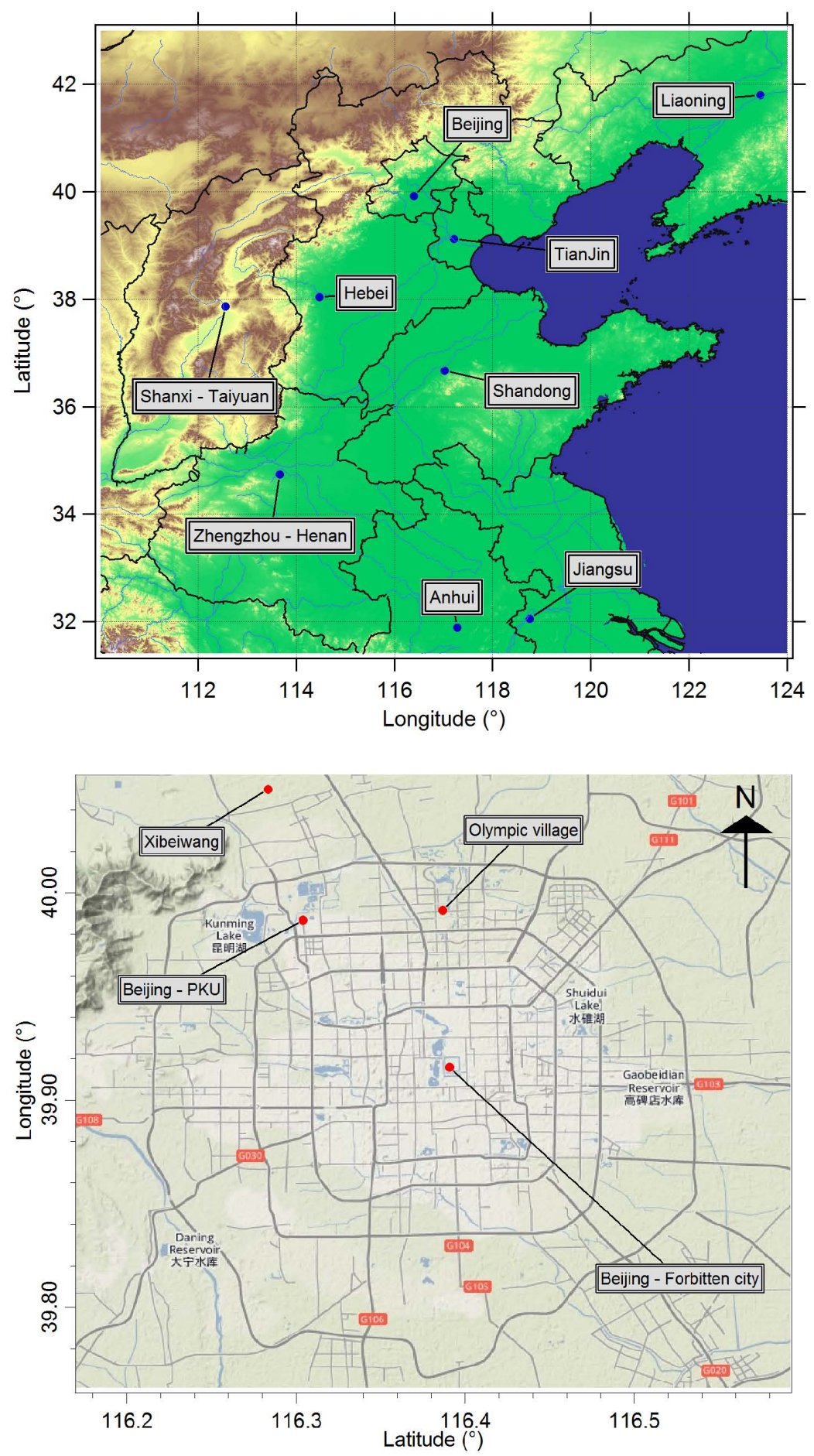

Fig. 4. Beijing city and measurement site (bottom) and surrounding regions (top).

site (PKU) were calculated for two days of winter intensive measurements (Fig. 7). The trajectories at $100 \mathrm{~m}$ arrival height above ground level were computed every 2-h (from 01:00 on 9 February to 23:00 on 10 February, local time) by using the NOAA ARL HYSPLIT trajectory model
(http://ready.arl.noaa.gov./HYSPLIT.php). Figure 7 shows dominant transport of air masses from northwest (83\%) of Beijing coinciding with the direction of Inner Mongolia and agricultural areas such as Hebei province, which completely surrounds Beijing and Tianjin municipalities. 


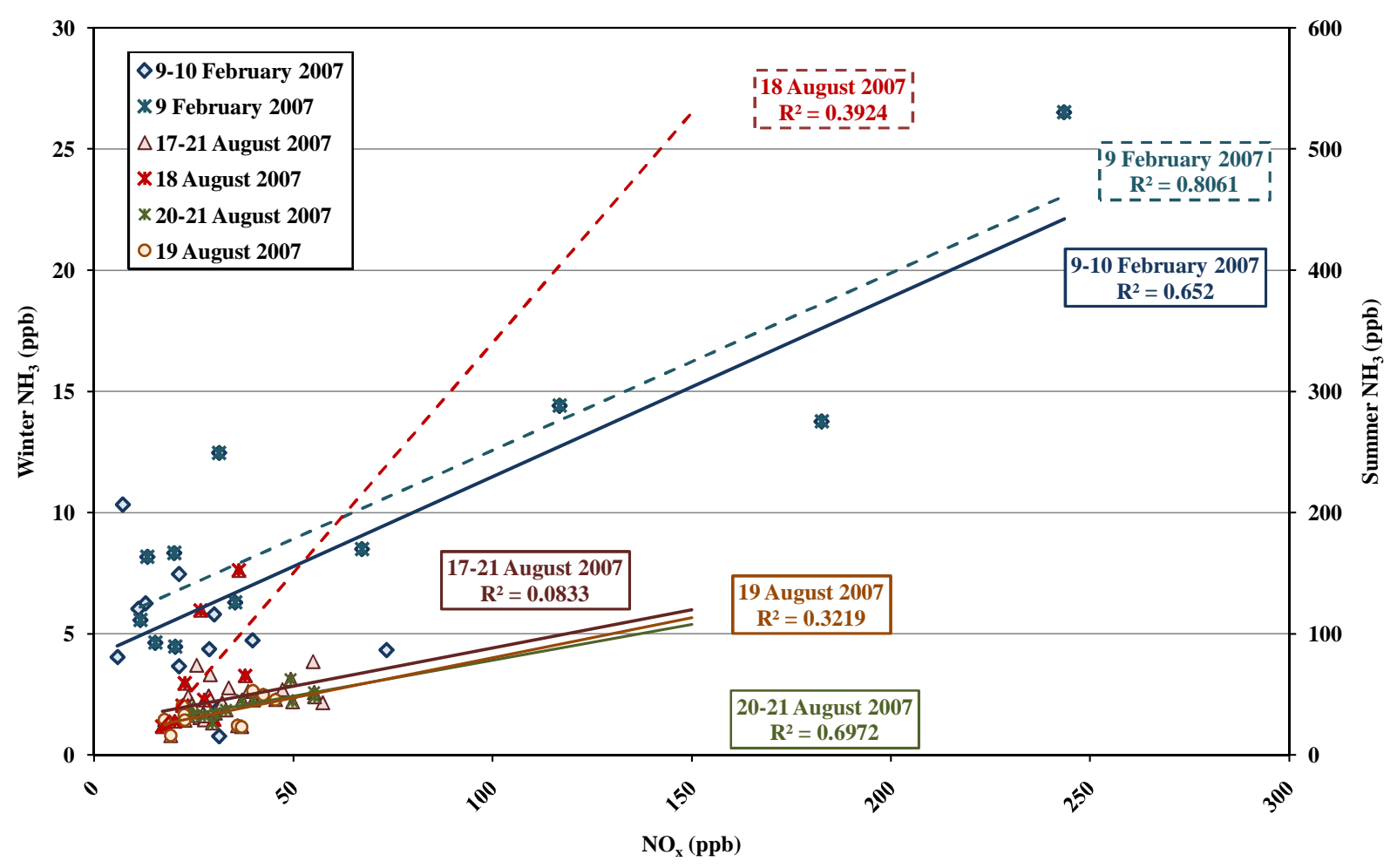

Fig. 5. Relationship between $\mathrm{NH}_{3}$ and $\mathrm{NO}_{\mathrm{x}}$ during the intensive winter and summer measurements.

Actually, intensive agriculture is concentrated in the North China Plain which includes five provinces (Hebei, Henan, Shangdong, Jiangsu and Anhui) and two municipalities (Beijing and Tianjin). Of the total agricultural ammonia emissions in the North China Plain, the Hebei, Henan and Shandong provinces take the larger part (Zhang et al., 2010). Contributions of $\mathrm{NH}_{3}$ emissions from livestock and fertilizer activities were also found in Inner Mongolia (Klimont, 2001; Ju et al., 2004). Beijing is downwind of Shanxi, which is one of the largest coal mining and coal-fired power generation provinces in China, which can emit large amounts of $\mathrm{NH}_{3}$ (Meng et al., 2010). In addition, these air masses passing the northwestern regions arrived faster $(8.17-15.70 \mathrm{~m} / \mathrm{s})$ and, thus, they had less time to accumulate ammonia. Instead, as said above, on 9 February local wind speeds, especially between 00:00 and 12:00, coming principally from southeast and southwest of Beijing arrived slower and, thus, local air masses had much time to accumulate pollutants. This suggests that $\mathrm{NH}_{3}$ received the largest impacts from local emissions in the city of Beijing, where morning peaks of $\mathrm{NH}_{3}$, which correlated with morning traffic emissions, were observed.

In contrast, on 10 February local high wind speeds from the northwest dominated in Beijing, where the correlation between $\mathrm{NH}_{3}$ and both $\mathrm{CO}$ and $\mathrm{NO}_{\mathrm{x}}$ did not occur, in combination with temperature dipendence of $\mathrm{NH}_{3}$. This suggests a possible and further contribution of regional and agricultural sources, located to the northwest of Beijing, to the ammonia concentrations observed in Beijing during on 10 February.

These results reveal that during the winter $\mathrm{NH}_{3}$ concentrations are influenced by meteorological conditions (wind direction, wind speed and, sometimes, temperature), local and regional sources in the winter 2007 in Beijing. Further modeling studies are needed to quantify the contribution of local versus regional sources to the atmospheric ammonia variations.

\subsubsection{Summer}

During the intensive measurements the wind speed reached a maximum value of $3 \mathrm{~m} / \mathrm{s}$ at 18:00 in the afternoon, the wind blew mainly from south and northwest (Fig. 8). In addition, the air temperature and relative humidity reached a value of about $35^{\circ} \mathrm{C}$ and $90 \%$, respectively.

The mean level of ammonia within \pm one standard deviation for the entire data $(N=47)$ was $31.84 \pm 16.57 \mu \mathrm{g} / \mathrm{m}^{3}$. As in winter, the diurnal variation of ammonia is not statistically significant $(p=0.53)$ in the summer (Fig. 8). Usually, broad peaks of $\mathrm{NH}_{3}$ concentrations were observed in the morning (between 06:00, and 10:00), as higher ammonia emissions occurred in summer, with one exception of 19 August at 20:00 in the evening. As suggested by other studies, the transport of $\mathrm{NH}_{3}$ from downwind sources was the cause of higher daytime concentrations, while dry deposition 


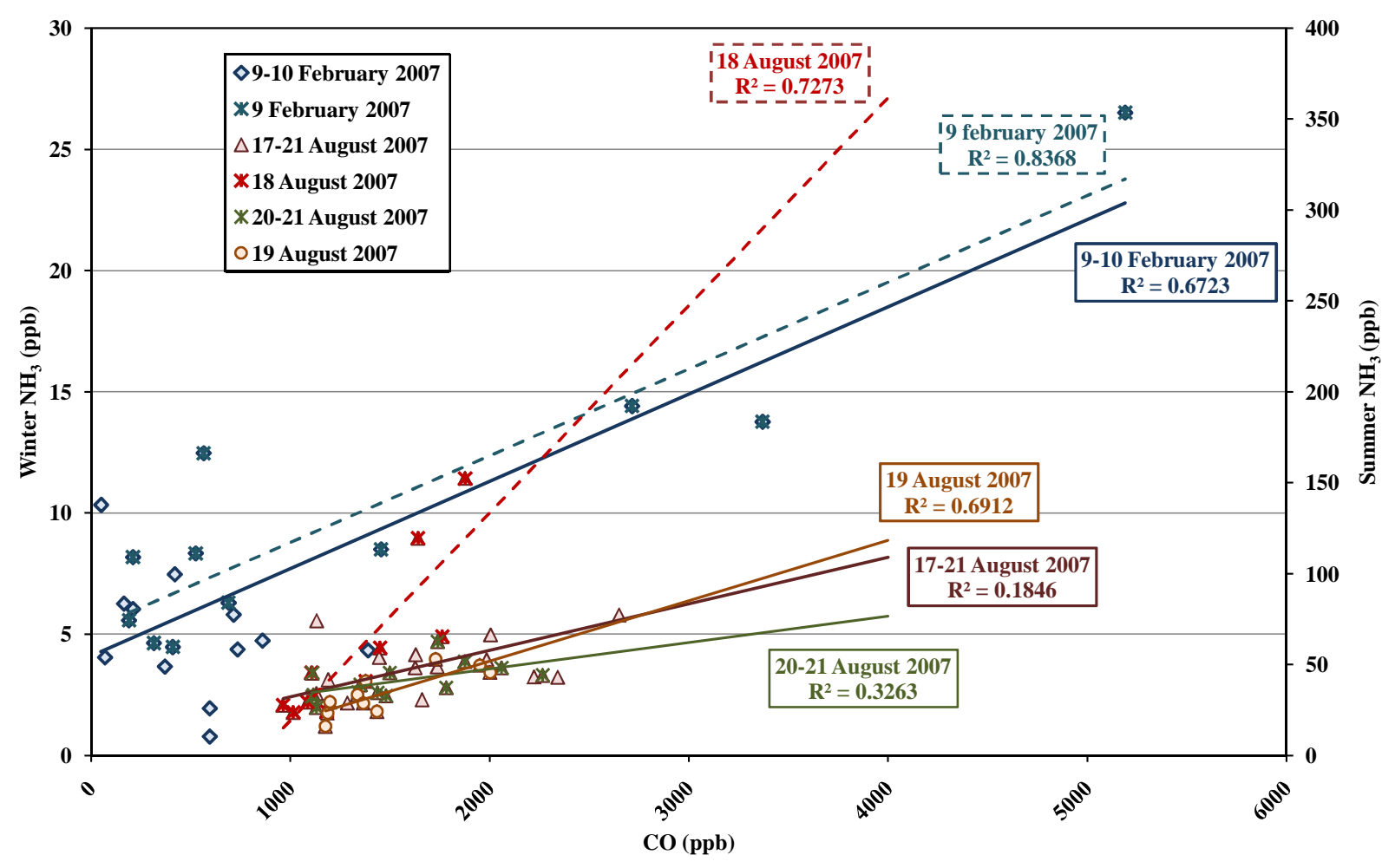

Fig. 6. Relationship between $\mathrm{NH}_{3}$ and $\mathrm{CO}$ during the intensive winter and summer measurements.

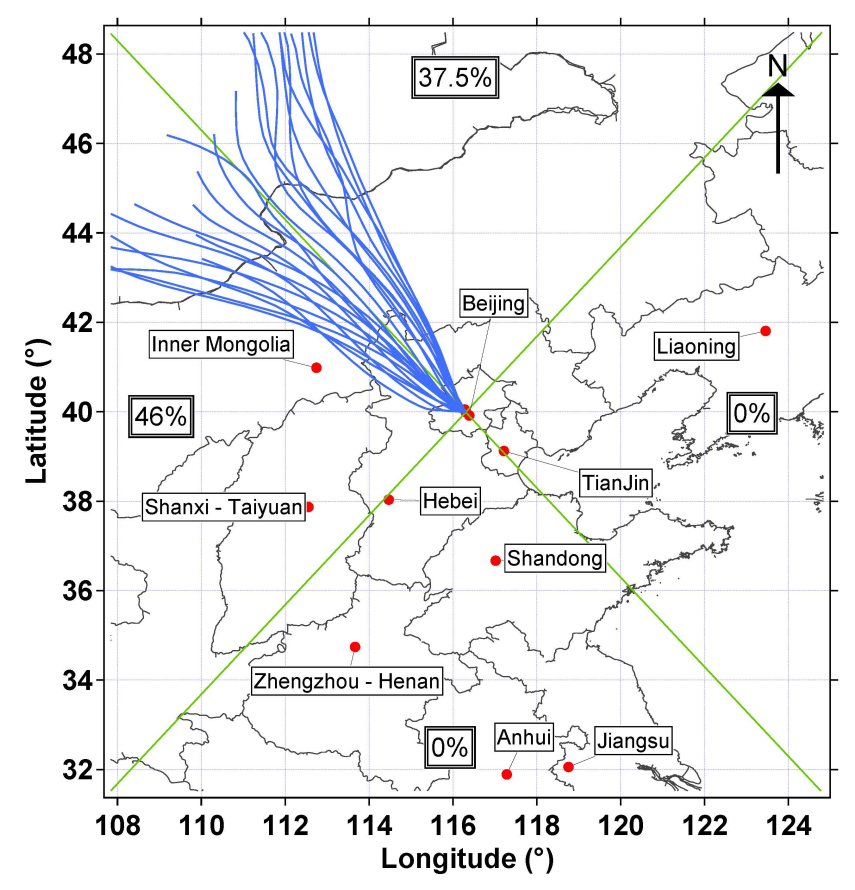

Fig. 7. Geographical map showing the 24-h backward trajectories arriving at Beijing during the intensive winter measurements, reconstructed using the NOAA ARL HYSPLIT trajectory model (http://ready.arl.noaa.gov./HYSPLIT.php). and conversion to aerosol may exceed the contribution from transport at night, resulting in higher concentrations during the day.

However, the highest ammonia concentrations were principally observed when the wind was from the northwest during low wind conditions (Fig. 8), reflecting the large contribution due to agricultural activity and fertilizer use. A moderate but significant linear correlation $\left(R^{2}=0.29\right.$, $p<0.001)$ was detected between natural-log transformed ammonia concentrations and wind speeds (Robarge et al., 2002).

In addition, the diurnal pattern of ammonia did not show a clear and well-defined temperature dependence during the summer field campaign, as it was in the winter. The temperature dependence of $\mathrm{NH}_{3}$ can be examined further by filtering all the data by hours of day and, for only particular hours during all days of intensive summer measurements (from 06:00 to 12:00 on 17 August, from 00:00 to 10:00 on 18 August, from 02:00 to 10:00 on 19 August, from 02:00 to 12:00 on 20 August, from 02:00 to 06:00 on 21 August), there is a weak but significant correlation between temperature and $\mathrm{NH}_{3}$ concentration (at the $99.9 \%$ confidence level, $R^{2}=0.22, p=0.03$ ) with prevailing winds from northwest. As said for winter period, this weak temperature dependence of $\mathrm{NH}_{3}$ reflects the influence of the emission sources from agricultural activity coming from northwest suburb of Beijing (Shen et al., 2009; Zhang et al., 2010). The temperature 


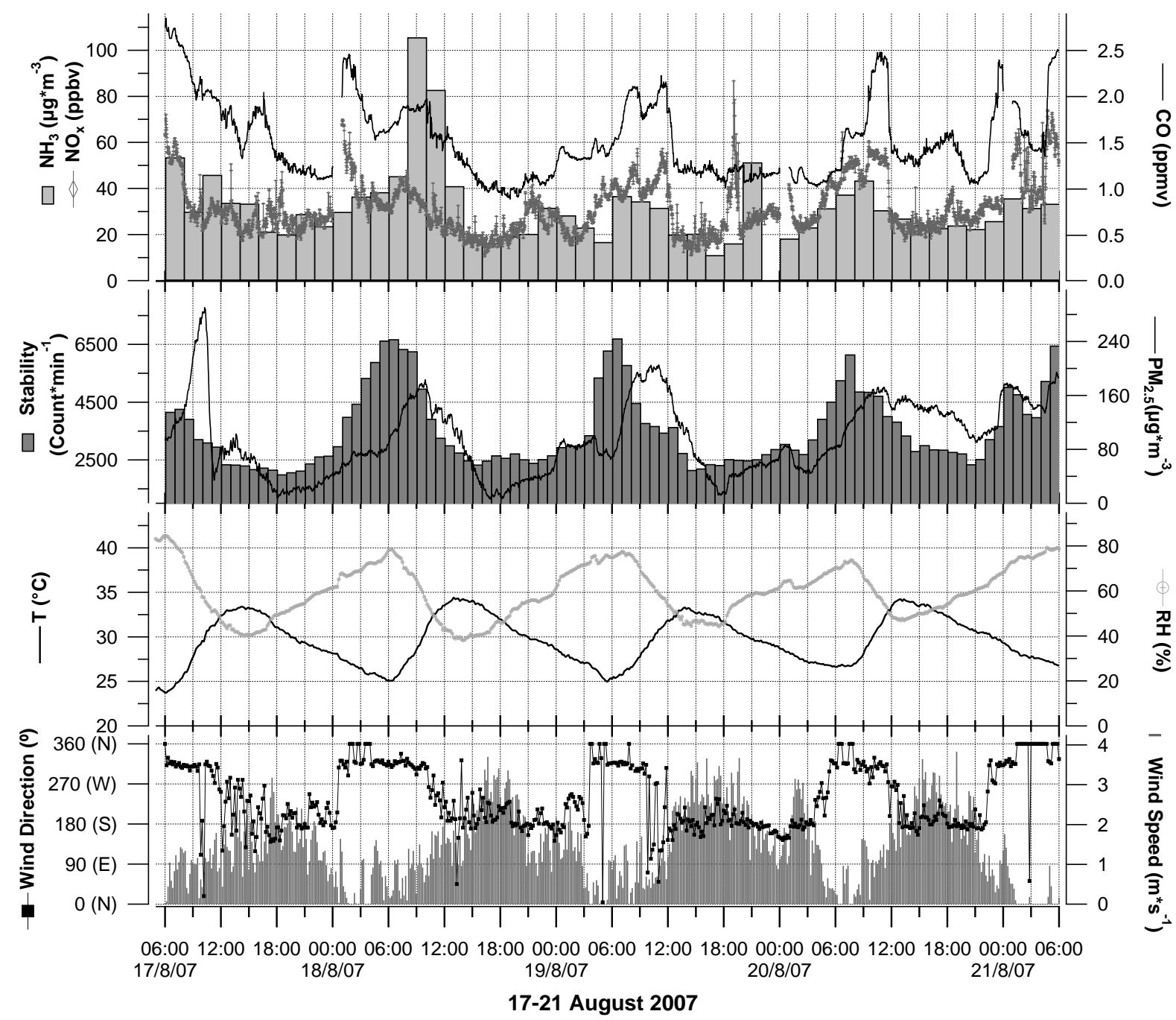

Fig. 8. Diurnal trends of $\mathrm{NH}_{3}, \mathrm{NO}_{\mathrm{x}}, \mathrm{CO}, \mathrm{PM}_{2.5}$, temperature $(T)$, relative humidity $(\mathrm{RH})$, wind speed and direction during the intensive summer measurements.

dependence of $\mathrm{NH}_{3}$ disappeared for the other hours of every day with prevailing winds from south and southwest. This different behaviour may be explained from prevalence of local sources, such as traffic emissions, in determining the atmospheric $\mathrm{NH}_{3}$ concentrations during this summer period.

The data in Fig. 8 show that $\mathrm{NH}_{3}, \mathrm{CO}$ and $\mathrm{NO}_{\mathrm{x}}$ had similar temporal patterns, but the correlations between these species were not good. A weak but significant linear correlation occurred between $\mathrm{NH}_{3}$ and $\mathrm{CO}\left(R^{2}=0.18, p<0.001\right)$ (Fig. 6) for all sampling period (17-21 August 2007). For the $\mathrm{NH}_{3}$ and $\mathrm{NO}_{\mathrm{x}}$ data, this correlation did not occur (Fig. 5). However, for the $\mathrm{CO}$ data, the best relationships with correlation coefficients of $0.73(p<0.001), 0.69(p=0.03)$ and 0.33 ( $p=0.03)$ were obtained considering concentrations measured only on 18, 19 and 20-21 August 2007, respectively, during the formation of the higher peaks of $\mathrm{NH}_{3}$ and $\mathrm{CO}$ supporting the hypothesis that the traffic is also a important mobile source of $\mathrm{NH}_{3}$. In addition, for the $\mathrm{NO}_{\mathrm{x}}$ data, the best re- lationships with correlation coefficients of $0.39(p<0.001)$, $0.32(p=0.03)$ and $0.70(p=0.001)$ were also obtained considering concentrations measured for the same days, respectively, in correspondence with the highest concentrations of $\mathrm{NH}_{3}$ and $\mathrm{NO}_{\mathrm{x}}$. $\mathrm{NO}_{\mathrm{x}}$ and $\mathrm{CO}$ peaks were observed between 06:00 and 10:00 during all days, in combination with northwesterly wind direction and low wind speeds $(0.3-1.2 \mathrm{~m} / \mathrm{s})$. Winds from the south were dominant at the sampling site for the other hours of day, in combination with the locations of the sources of $\mathrm{NO}_{\mathrm{x}}$ and $\mathrm{CO}$ emissions. However, the amount of scatter about these regression lines indicates that other ammonia sources not linked to $\mathrm{NO}_{\mathrm{x}}$ and $\mathrm{CO}$ are also significant. In addition, the correlations between $\mathrm{NH}_{3}$ and both $\mathrm{NO}_{\mathrm{x}}$ and $\mathrm{CO}$ were weaker than that in the winter, suggesting that other, non-traffic sources, became significant. The higher temperatures in the summer will increase ammonia emission from agricultural sources, resulting in the breakdown in the relationship between these gases. 


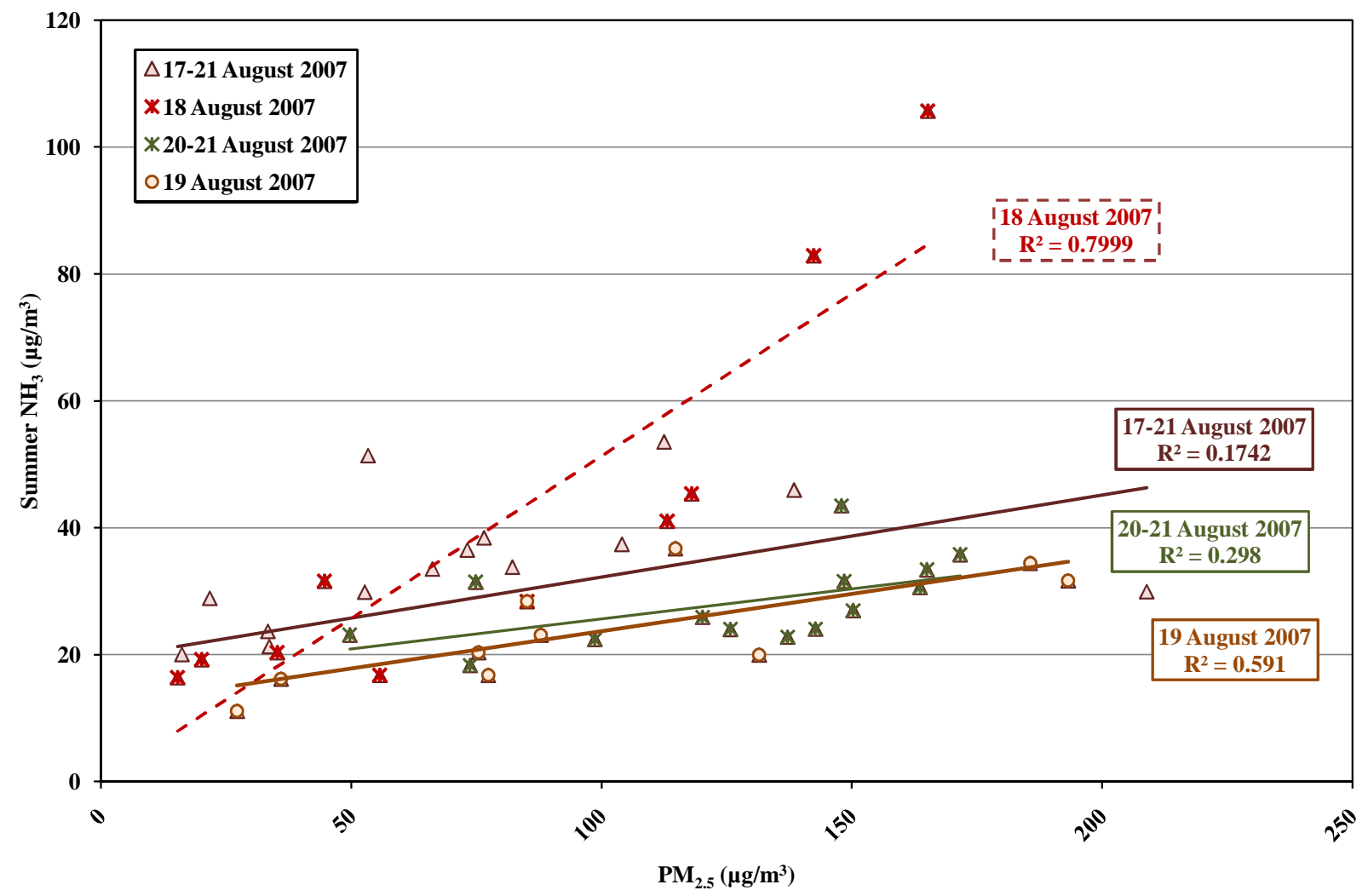

Fig. 9. Relationship between $\mathrm{NH}_{3}$ and $\mathrm{PM}_{2.5}$ during the intensive summer measurements.

The same findings were also observed comparing the ammonia concentrations with those of $\mathrm{PM}_{2.5}$ which accounts for $90 \%$ of total PM emissions from on-road vehicles in Beijing (Zheng et al., 2005). $\mathrm{PM}_{2.5}$ peaks were observed between 08:00 and 10:00 during all days (Fig. 8). A weak but significant linear correlation occurred between $\mathrm{NH}_{3}$ and $\mathrm{PM}_{2.5}\left(R^{2}=0.17, p=0.004\right)$ (Fig. 9) for all sampling period. However, for the $\mathrm{PM}_{2.5}$ data, the best relationships with correlation coefficients of $0.80(p<0.001), 0.60(p=0.009)$ and $0.30(p=0.03)$ were obtained considering concentrations measured only on 18, 19 and 20-21 August 2007, respectively, during the formation of the higher peaks of $\mathrm{NH}_{3}$ and $\mathrm{PM}_{2.5}$ supporting the hypothesis that the traffic is also a important mobile source of $\mathrm{NH}_{3}$.

The highest ammonia values during the day can be also attributed to stable atmosphere conditions. The analysis of the temporal pattern of natural radioactivity (Fig. 8) shows that the convective mixing of the atmosphere occurs between the late morning (12:00-13:00 a.m.) of the previous day and the early morning of the subsequent day (03:00-04:00 a.m.). Subsequently, a rapid increase of natural radioactivity determines atmospheric stability with high values at 06:00 and at 08:00 in the morning. In these conditions, pollution events are generally favoured. This implies that most of the traffic emission is injected into a stagnant atmosphere causing the sharp increase in the concentration of ammonia, which reached the remarkable value of $105.67 \mu \mathrm{g} / \mathrm{m}^{3}$ (18 August 2007), one of the highest values during the intensive measurements. During the same hours $\mathrm{CO}$ and $\mathrm{NO}_{\mathrm{x}}$ concentrations reached the levels of $2.15 \mathrm{mg} / \mathrm{m}^{3}$ and $112.6 \mu \mathrm{g} / \mathrm{m}^{3}$ (Fig. 6), respectively, and this is an indication of a common origin of these pollutants, i.e., traffic emission (Perrino et al., 2002; Edgerton et al., 2007).

In some studies, increased $\mathrm{NH}_{3}$ concentrations have also been attributed to the dissociation of particulate ammonium nitrate (Langford et al., 1992; H. S. Lee et al., 1999; Possanzini et al., 1999). Volatilization of $\mathrm{NH}_{3}$ from the aerosol phase may be significant enough to dominate over traffic emissions during the summer (Whitehead et al., 2007) and mask any correlations with traffic related pollutants. It is known that volatile ammonium salts collected on the Teflon filter $\left(\mathrm{NH}_{4} \mathrm{Cl}\right.$ and $\left.\mathrm{NH}_{4} \mathrm{NO}_{3}\right)$ dissociate to $\mathrm{HCl}$ and $\mathrm{HNO}_{3}$, a phenomenon which depends mainly upon meteorological conditions (air temperature and relative humidity), on the aerosol composition, and on the acidity of the particles. In this work the gases evolved from the front Teflon filters were recovered on the back-up Nylon and phosphorous acidimpregnated filters. Data from 2-h sampling over the 17-21 August period showed that Teflon filters exhibited a nearly complete depletion of nitrate and chloride $(>90 \%)$ which were recovered on Nylon filters. This indicated that nitrate and chloride were almost entirely associated to ammonium. 
Indeed, a comparison of $\mu \mathrm{mol}$ amount of $\mathrm{NH}_{4}^{+}$with $\mu \mathrm{mol}$ amounts of anions $\left(\mathrm{NO}_{3}^{-}+\mathrm{Cl}^{-}\right)$determined on the back-up filters showed a good and significant correlation $\left(R^{2}=0.80\right.$, $p<0.001$ ). However, the diurnal variation in $\mathrm{NH}_{3}$ concentrations had a similar trend as for $\mathrm{NH}_{4}^{+}$, with one exception of 17 August. During this day, the formation of aerosol $\mathrm{NH}_{4}^{+}$leads to the decrease of $\mathrm{NH}_{3}$ concentrations and vice versa. This behaviour could be explained with the displacement of the thermodynamic equilibrium between ammonium salts and their gaseous precursors. While for the other days (18-21 August), the fact that the $\mathrm{NH}_{3}$ and $\mathrm{NH}_{4}^{+}$exhibited similar patterns is due to dissolution of a significant fraction of $\mathrm{NH}_{3}$ in humid aerosols under high relative humidity conditions (Hesterberg et al., 1996; Krupa, 2003; Trebs et al., 2004, 2005; Hu et al., 2008). In fact, the concentrations of ammonia and ammonium reach the maximum values at the same time (between 06:00 and 10:00). Possible evaporation of $\mathrm{NH}_{3}$ from wet surfaces due to temperature increase just after sunrise, when relative humidity was still high might have caused a significant fraction of gaseous $\mathrm{NH}_{3}$ to dissolve in still deliquescent aerosols, therefore enhancing aerosol $\mathrm{NH}_{4}^{+}$.

A more detailed study of the behaviour of ammonia and ammonium salts in the atmosphere may be carried out considering the mass balance on back-up filters. In fact, in principle we should find equimolecular amounts of anions $\left(\mathrm{Cl}^{-}+\mathrm{NO}_{3}^{-}\right)$and of evaporated ammonia $\left(\mathrm{NH}_{3 \mathrm{ev}}\right)$ determined on the back-up filters. On the contrary, the results reported in Fig. 10 show that during the intensive measurements in the summer period, ammonia frequently exceeded the sum of chloride and nitrate. This unbalance can be regarded as an additional phenomenon which adds ammonia to the dissociation of ammonium nitrate and chloride; a possible explanation is the presence of other anions (e.g. organic matter) or of gaseous ammonia adsorbed or dissolved in deliquescent aerosol $\left(\mathrm{NH}_{3 \mathrm{ads}}\right)$, as said before, which is desorbed from the collected fine particulate matter during the sampling and is then recovered on the back-up acid-coated filters, as already seen in previous studies (Perrino and Gherardi, 1999). This unbalanced amount of ammonia, ranged from $0.06 \mu \mathrm{mol} / \mathrm{m}^{3}\left(1.15 \mu \mathrm{g} / \mathrm{m}^{3}\right)$ to $0.72 \mu \mathrm{mol} / \mathrm{m}^{3}\left(13 \mu \mathrm{g} / \mathrm{m}^{3}\right)$ with an average value of about $0.26 \mu \mathrm{mol} / \mathrm{m}^{3}\left(4.75 \mu \mathrm{g} / \mathrm{m}^{3}\right)$ during the summer sampling period. The value of 0 indicated that ammonia is in balance on back-up filters (Fig. 10). The unbalanced ammonia, clearly adsorbed on particles, can be a further source of atmospheric ammonia during specific meteorological conditions such as dry and warm and windy environments.

As in winter, to help interpret further in general terms the source regions affecting the sampled ammonia and, thus, to identify the origin and transport pathway of large-scale air masses, 24-h backward trajectories arriving at the sampling site were also calculated for five days of summer intensive measurements (Fig. 11). The trajectories were computed every $2 \mathrm{~h}$ (from 07:00 on 17 August 2007 to 05:00 on 21

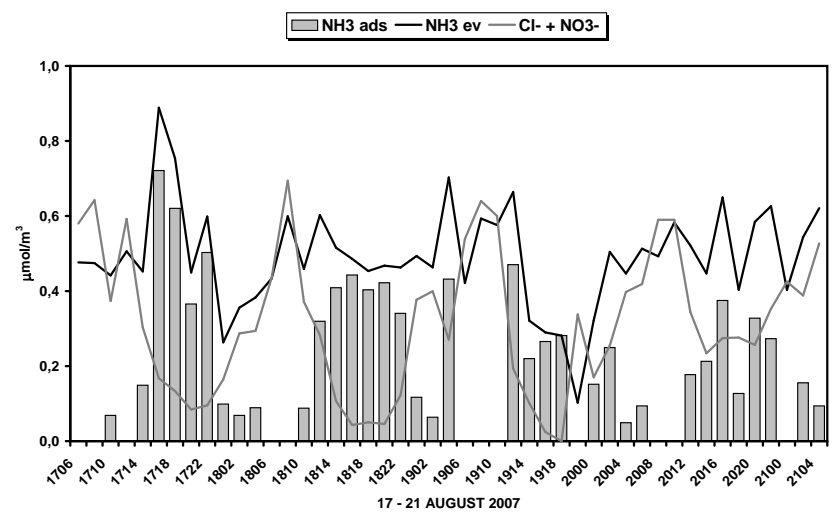

Fig. 10. Comparison between the amounts of evaporated ammonia $\left(\mathrm{NH}_{3 \mathrm{ev}}\right)$ and of its anions $\left(\mathrm{Cl}^{-}+\mathrm{NO}_{3}^{-}\right)$on the back-up filters and trend of unbalanced ammonia $\left(\mathrm{NH}_{3}\right.$ ads on particulate $)$ during the intensive summer measurements at PKU site.

August, local time). The Fig. 11 shows dominant and regional transport of air masses from south (53\%) and southeast $(15 \%)$ of Beijing, which are the most frequent in summer time, coinciding with the direction of Hebei province and Tianjin municipalities, which are not only agricultural areas but also quite polluted by industrial, vehicular, coal mining and power generation, and biomass burning emissions (Xia et al., 2007; Street et al., 2007; Chen et al., 2009; Meng et al., 2009; Zhang, 2010). In addition, these air masses passing the southern regions were relatively slow $(1.63-3.85 \mathrm{~m} / \mathrm{s})$ and, thus, they had much time to accumulate ammonia in the Beijing area, contributing greatly to the air pollution. The urban area itself is a major source for traffic emissions. This suggests that the atmosphere of Beijing received transported polluted air on locally produced $\mathrm{NH}_{3}$.

Thus, the presence of local and regional sources during summer intensive measurements probably explains why the temperature did not determine $\mathrm{NH}_{3}$ concentrations and a diurnal cycle of this gas in Beijing was not observed due to variation in emissions.

These results reveal that during the summer $\mathrm{NH}_{3}$ concentrations are influenced by meteorological conditions (wind direction, wind speed and, sometimes, temperature), atmospheric mixing, local and regional sources in the summer 2007 in Beijing. Further modeling studies are needed to quantify the contribution of local versus regional sources to the atmospheric ammonia variations.

\subsection{Emission estimates}

The Table 2 shows the mean emission factors of $\mathrm{NH}_{3}$ for transport vehicles and agricultural activities believed to contribute mainly to the concentrations of $\mathrm{NH}_{3}$ in Beijing. This investigation of emission inventory within Beijing was conducted with the base year being taken 2005 , by using atmospheric $\mathrm{NH}_{3}$ emission information by current literatures. 


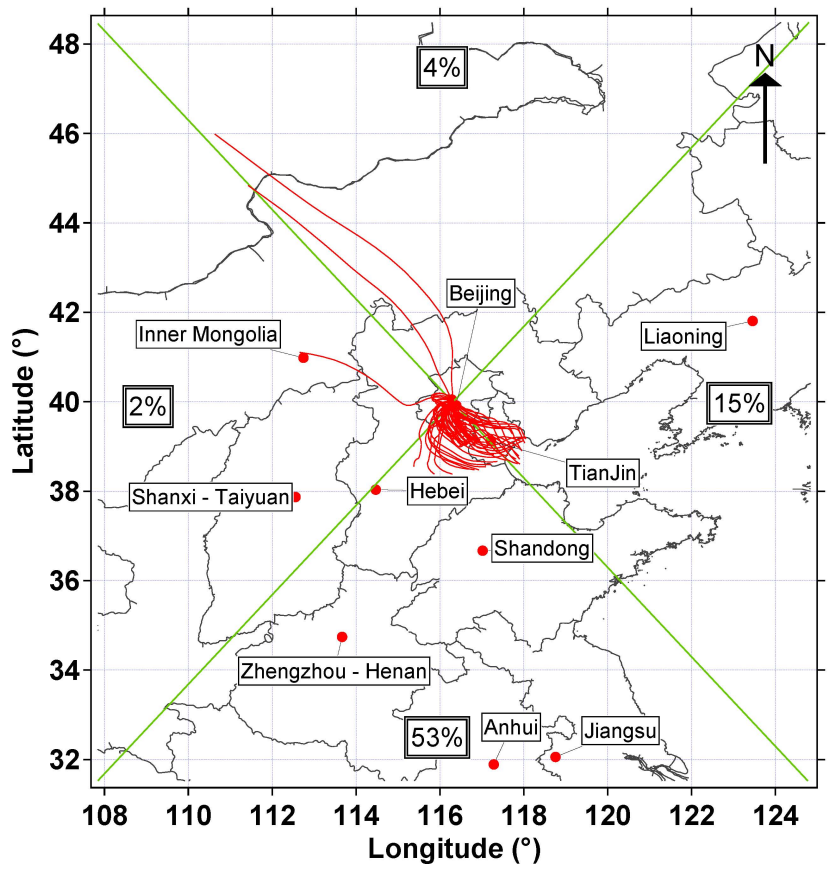

Fig. 11. Geographical map showing the 24-h backward trajectories arriving at Beijing during the intensive summer measurements, reconstructed using the NOAA ARL HYSPLIT trajectory model (http://ready.arl.noaa.gov./HYSPLIT.php).

There are not many published data available for the $\mathrm{NH}_{3}$ emissions in China and, thus, only limited data have been found and used.

Vehicle emission inventory for regional or national scale are usually developed using a macro-scale approach in China. H. Wang et al. $(2009,2010)$ provided a bottom-up approach by combining vehicle emission factors and vehicle activity data from a travel demand model estimated at the grid level to generate vehicle emissions data for the Beijing urban area in 2005. Average vehicle activity data, such as Vehicle Kilometers Traveled (VKT), are estimated by investigation and/or a statistical method for each fleet. The emissions inventory is estimated as the product of emission factors and vehicle activity:

$Q^{P}=\sum_{i=1}^{m} \sum_{j=1}^{n} \mathrm{EF}_{i, j}^{P} \mathrm{VKT}_{i, j}$

where, $Q^{P}$ is the total emissions for pollutant $P, \mathrm{~g} ; \mathrm{EF}_{i, j}^{P}$ is the emission factor of pollutant $P$ for vehicle type $i$ in grid cell $j, \mathrm{~g} / \mathrm{km} ; \mathrm{VKT}_{i, j}$ is the vehicle kilometers traveled for vehicle type $i$ in grid cell $j, \mathrm{~km}$.

For these applications, emission factors are assumed to represent long-term vehicle population averages for a given vehicle class, and are often based on default or average inputs. In this study, the vehicles driving in the urban area of Beijing were summarized into 6 classes: passenger car (PC), shuttle bus (SB), taxi, heavy duty truck (HDT), light duty truck (LDT) and bus. Because the light duty vehicles (PCs
Table 2. $\mathrm{NH}_{3}$ emission estimates $\left(\mathrm{Kt} \mathrm{NH}_{3}-\mathrm{N} \mathrm{yr}^{-1}\right)$ in Beijing and surrounding areas in 2005.

\begin{tabular}{lrr}
\hline Provinces & Transport & Agriculture \\
\hline Beijing & 1.8 & 3.6 \\
Hebei & 2.6 & 706.8 \\
Taijing & 1.4 & 87.6 \\
Inner Mongolia & & 246 \\
\hline
\end{tabular}

and taxies) are the main sources of traffic emissions in the city comprising over $90 \%$ of the total VKT in the urban area of Beijing, we considered only these vehicles for the $\mathrm{NH}_{3}$ emission inventory.

Heeb et al. $(2006,2008)$ reported mean $\mathrm{NO}$ and $\mathrm{NH}_{3}$ emission factors $\left(\mathrm{mg} \mathrm{km}^{-1}\right)$ and average vehicle speed $\left(\mathrm{km} \mathrm{h}^{-1}\right)$. In an urban area they calculated $\mathrm{NH}_{3}$ emission factor of $48.8 \mathrm{mg} \mathrm{km}^{-1}$ at $19 \mathrm{~km} \mathrm{~h}^{-1}$. Taking into account that since 2008 the total number of vehicles registered in Beijing city had increased to about 3.3 million and is still increasing by more than $10 \%$ per year (B. Wang et al., 2010), we calculated the total $\mathrm{NH}_{3}$ emission from traffic sources in Beijing and in surrounding areas (Street et al., 2003; Wang et al., 2005).

Furthermore, Zhang et al. (2010) developed an agricultural $\mathrm{NH}_{3}$ emission inventory in the North China Plain (NCP), calculating contributions of $\mathrm{NH}_{3}$ emissions from different sources including Beijing and Tianjing municipalities. However, the largest sector contributor to $\mathrm{NH}_{3}$ emissions in the NCP is agriculture (99\%). Mineral fertilizer use contributed $54 \%$ to the total $\mathrm{NH}_{3}$ emission in the NCP, while livestock sources contributed the remaining $46 \%$. Thus, we also considered these contributions to agricultural $\mathrm{NH}_{3}$ emission from Beijing and surrounding areas such as Taijing municipalities, Hebei province and Inner Mongolia.

These results show that $\mathrm{NH}_{3}$ emissions from agriculture are high as $3.6 \mathrm{KtNH}_{3}-\mathrm{N} \mathrm{yr}^{-1}$ in Beijing in 2005 corresponding to two times that from traffic sources $\left(1.8 \mathrm{Kt} \mathrm{NH}_{3}\right.$ $\mathrm{Nyr}^{-1}$ ). Thus, even if $\mathrm{NH}_{3}$ emissions from road traffic mainly affect the air quality in urban environments as Beijing, however, the agricultural emissions can be also of major importance affecting substantially the observed $\mathrm{NH}_{3}$ concentrations in Beijing, in combination with meteorological conditions and regional sources. In fact, the contribution of surrounding areas to $\mathrm{NH}_{3}$ emissions could be higher than $1000 \mathrm{Kt} \mathrm{NH}_{3}-\mathrm{N} \mathrm{yr}^{-1}$.

However, it is indeed very difficult to isolate the effects of local emission, regional sources and changes in meteorology. Our measurement data clearly illustrate the impact and importance of meteorology and regional sources on the observed $\mathrm{NH}_{3}$ concentrations in Beijing. 


\section{Conclusions}

The atmospheric concentrations of $\mathrm{NH}_{3}$ have been measured at an urban site (Peking University) in Beijing in the winter and summer of 2007. All data were analyzed to investigate temporal variations, meteorological effects and special features of the gas-particulate equilibrium. According to the results, the following conclusions were reached:

- The $\mathrm{NH}_{3}$ concentrations showed regular temporal variations, having significantly higher summertime concentrations. The temporal trends seemed to be largely dominated by air temperature.

- The $\mathrm{NH}_{3}$ concentrations did not show any diurnal variation in both winter and summer seasons.

- The effects of wind direction and of the atmospheric mixing on the $\mathrm{NH}_{3}$ concentrations were the two most significant meteorological parameters. The $\mathrm{NH}_{3}$ concentrations were slightly affected by wind speed and temperature.

- Moderate correlations were obtained between $\mathrm{NH}_{3}$ and pollutants mainly emitted by motor-vehicle exhausts, such as $\mathrm{NO}_{\mathrm{x}}, \mathrm{CO}$ and $\mathrm{PM}_{2.5}$, indicating an influence by traffic emissions at Beijing.

- Emissions from regional sources contributed also to the atmospheric ammonia variations in winter and summer seasons at Beijing.

Acknowledgements. We would like to thank the "Blue Sky of Beijing: Research on Regional Air Pollution Project", the Beijing Municipal Environmental Protection Bureau and the Italian Ministry for the Environment; Land and Sea (IMELS) of Italy for the financial support through the Sino-Italian Cooperation Program, and the Beijing Council of Science and Technology (HB200504-6, HB200504-2) for supporting Peking University to organize the field study CAREBEIJING.

Edited by: M. Gauss

\section{References}

Allegrini, I., De Santis, F., Di Palo, V., Febo, A., Perrino, C., Possanzini, M., and Liberti, A.: Annular denuder method for sampling reactive gases and aerosols in the atmosphere, Sci. Total Environ., 67, 1-16, 1987.

Allegrini, I., Ianniello, A., Montagnoli, M., Sparapani, R., and Mazzioti Gomez de Teran, C.: Carbon coated annular denuders and ion chromatographic measurements for the determination of nitrogen-containing species $\left(\mathrm{NO}_{2}\right.$ and $\left.\mathrm{NO}_{\mathrm{y}}\right)$ in remote atmospheres, J. Chromatogr. A, 846, 265-268, 1999.

Aneja, V. P., Chauhan, J. P., and Walker, J. T.: Characterization of atmospheric ammonia emissions from swine waste storage and treatment lagoons, J. Geophys. Res., 105, 11535-11545, 2000.
Aneja, V. P., Roelle, P. A., Murray, G. C., Southerland, J., Erisman, J. W., Fowler, D., Asman, W. A. H., and Patni, N.: Atmospheric nitrogen compounds: II. Emissions, transport, transformation, deposition and assessment, Atmos. Environ., 35, 19031911, 2001.

Asman, W. A., Sutton, M. A., and Schjorring, J. K.: Ammonia: emission, atmospheric transport, and deposition, New Phytol., 139, 27-48, 1998.

Bari, A., Ferraro, V., Wilson, L. R, Luttinger, D., and Husain, L.: Measurements of gaseous $\mathrm{HONO}, \mathrm{HNO}_{3}, \mathrm{SO}_{2}, \mathrm{HCl}, \mathrm{NH}_{3}$, particulate sulfate and $\mathrm{PM}_{2.5}$ in New York, NY, Atmos. Environ., 37, 2825-2835, 2003.

Battye, W., Aneja, V. P., and Roelle, P.: Evaluation and improvement of ammonia emissions inventories, Atmos. Environ., 37, 3873-3883, 2003.

Beine, H. J., Allegrini, I., Sparapani, R., Ianniello, A., and Valentini, F.: Three years of springtime trace gas and particle measurements at Ny-Ålesund, Svalbard, Atmos. Environ., 35, 36453658, 2001.

Bouwman, A. F., Lee, D. S., Asman, W. A. H., Dentener, F. J., Van der Hoek, K. W., and Olivier, J. G. J.: A global high-resolution emission inventory for ammonia, Global Biogeochem. Cy., 11, 561-587, 1997.

Brunekreef, B. and Holgate, S. T.: Air pollution and health, Lancet, 360, 1233-1242, 2002.

Burkhardt, J., Sutton, M. A., Milford, C., Storeton-West, R. L., and Fowler, D.: Ammonia concentrations at a site in southern Scotland from $2 \mathrm{yr}$ of continuous measurements, Atmos. Environ., 32, 325-331, 1998.

Cadle, S. H., Countessand, R. J., and Kelley, N. A.: Nitric acid and ammonia in urban and rural locations, Atmos. Environ., 16, 2501-2506, 1982.

Cape, J. N., Tang, Y. S., Van Dijk, N., Love, L., Sutton, M. A., and Palmer, S. C. F.: Concentrations of ammonia and nitrogen dioxide at roadside verges, and their contribution to nitrogen deposition, Environ. Pollut., 132, 469-478, 2004.

Carmichael, G. R., Ferm, M., Thongboonchoo, N., Woo, J.-H., Chan, L.Y., Murano, K., Viet, P. H., Mossberg, C., Bala, R., Boonjawat, J., Upatum, P., Mohan, M., Adhikary, S. P., Shrestha, A. B., Pienaar, J. J., Brunke, E. B., Chen, T., Jie, T., Guoan, D., Peng, L. C., Dhiharto, S., Harjanto, H., Jose, A. M., Kimani, W., Kirouane, A., Lacaux, J.-P., Richard, S., Barturen, O., Cerda, J. C., Athayde, A., Tavares, T., Cotrina, J. S., and Bilici, E.: Measurements of sulfur dioxide, ozone and ammonia concentrations in Asia, Africa, and South America using passive samplers, Atmos. Environ., 37, 1293-1308, 2003.

Chak, C. K. and Yao, X.: Air pollution in mega cities in China - A review, Atmos. Environ., 42, 1-42, 2008.

Chan, C. Y., Xu, X. D., Li, Y. S., Wong, K. H., Ding, G. A., Chan, L. Y., and Cheng, X. H.: Characteristics of vertical profiles and sources of $\mathrm{PM}_{2.5}, \mathrm{PM}_{10}$ and carbonaceous species in Beijing, Atmos. Environ., 39, 5113-5124, 2005.

Chen, D., Wang, Y., McElroy, M. B., He, K., Yantosca, R. M., and Le Sager, P.: Regional CO pollution and export in China simulated by the high-resolution nested-grid GEOS-Chem model, Atmos. Chem. Phys., 9, 3825-3839, doi:10.5194/acp-9-3825-2009, 2009.

Danalatos, D. and Glavas, S.: Gas phase nitric acid, ammonia and related particulate matter at a Mediterranean coastal site, Patras, 
Greece, Atmos. Environ., 33, 3417-3425, 1999.

Edgerton E. S., Saylor R. D., Hartsell B. E., Jansen J. J., Hansen D. A.: Ammonia and ammonium measurements from the southeastern United States, Atmos. Environ., 41, 3339-3351, 2007.

EMEP Webdab emission data hosted by the Centre on Emission Inventories and Projections (CEIP): http://www.ceip.at/, access: 20 August 2009.

Erisman, J. W. and Schaap, M.: The need for ammonia abatement with respect to secondary PM reductions in Europe, Environ. Pollut., 129, 159-163, 2004.

Fangmeier, A., Hadwiger-Fangmeier, A., van der Eerden, L., and Jaeger, H. J.: Effects of atmospheric ammonia on vegetation - A review, Environ. Pollut., 86, 43-82, 1994.

Febo, A., De Santis, F., Perrino, C., and Giusto, M.: Evaluation of laboratory and field performance of denuder tubes: a theoretical approach, Atmos. Environ., 23, 1517-1530, 1989.

Ferm, M.: Atmospheric ammonia and ammonium transport in Europe and critical loads: a review, Nutr. Cycl. Agroecosys., 51, 5-17, 1998.

Fraser, M. P. and Cass, G. R.: Detection of excess ammonia emissions from in use vehicles and the implications for fine particle control, Environ. Sci. Technol., 32, 1053-1057, 1998.

Goebes, M. D., Strader, R., and Davidson, C.: An ammonia emission inventory for fertilizer application in the United States, Atmos. Environ., 37, 2539-2550, 2003.

He, K., Yang, F., Ma, Y., Zhang, Q., Yao, X., Chan, C. K., Cadle, S., Chan, T., and Mulawa, P.: The characteristics of $\mathrm{PM}_{2.5}$ in Beijing, China, Atmos. Environ., 35, 4959-4970, 2001.

He, K., Huo, H., and Zhang, Q.: Urban air pollution in china: Current Status, Characteristics, and Progress, Annu. Rev. Energ. Env., 27, 397-431, 2002.

He, C.-E., Liu, X., Fangmeier, A., and Zhang, F.: Quantifying the total airborne nitrogen input into agroecosystems in the North China Plain, Agr. Ecosyst. Environ., 121, 395-400, 2007.

Hao, J., He, D., Li, L., Wu, Y., Fu, L., and He, K.: A study of the emission and concentration distribution of vehicular pollutants in the urban area of Beijing, Atmos. Environ., 34, 453-465, 2000.

Hao, J., Wang, L., Li, L., Hu, J. N., and Yu, X. C.: Air pollutants contribution and control strategies of energy-use related sources in Beijing, Sci. China Ser. D, 48, (Suppl. II), 138-146, 2005.

Heeb, N. V., Forss, A-M., Brühlmann, S., Lüscher, R., Saxer, C. J., and Hug, P.: Three-way catalyst-induced formation of ammonia velocity- and acceleration-dependent emission factors, Atmos. Environ., 40, 5986-5997, 2006.

Heeb, N. V., Saxer, C. J., Forss, A.-M., and Brühlmann, S.: Trends of $\mathrm{NO}-, \mathrm{NO}_{2-}$, and $\mathrm{NH}_{3}$-emissions from gasoline-fueled Euro3- to Euro-4-passenger cars, Atmos. Environ., 42, 2543-2554, 2008.

Hesterberg, R., Blatter, A., Fahrni, M., Rosset, M., Neftel, A., Eugster, W., and Wanner, H.: Deposition of nitrogen-containing compounds to an extensively managed grassland in central Switzerland, Environ. Pollut., 91, 21-34, 1996.

Horvath, H.: Effects on visibility, weather and climate, in: Atmospheric acidity: sources, consequences and abatement, edited by: Radojevic, M. and Harrison, R. M., chapter 13, London: Elsevier Applied Science, 1992.

Horvath, L. and Sutton, M. A.: Long term record of ammonia and ammonium concentrations at K-puszta, Hungary, Atmos. Environ., 32, 339-344, 1998.
Hu, M., Wu, Z., Slanina, J., Lin, P., Liu, S., and Zeng, L.: Acidic gases, ammonia and water-soluble ions in $\mathrm{PM}_{2.5}$ at a coastal site in the Pearl River Delta, China, Atmos. Environ., 22, 6310-6320, 2008.

Huai, T., Durbin, T. D., Miller, J. W., Pisano, J. T., Sauer, C. G., Rhee, S. H., and Norbeck, J. M.: Investigation of $\mathrm{NH}_{3}$ Emissions from New Technology Vehicles as a Function of Vehicle Operating Conditions, Environ. Sci. Technol., 37, 4841-4847, 2003.

Huai, T., Durbin, T. D., Younglove, T., Scora, G., Barth, M., and Norbeck, J. M.: Vehicle Specific Power Approach to Estimating On-Road $\mathrm{NH}_{3}$ Emissions from Light-Duty Vehicles, Environ. Sci. Technol., 39, 9595-9600, 2005.

Huber, C. and Kreutzer, K.: Three years of continuous measurements of atmospheric ammonia concentrations over a forest stand at the Hoglwald site in southern Bavaria, Plant Soil, 240, 13-22, 2002.

Ianniello, A., Beine, H. J., Sparapani, R., Di Bari, F., Allegrini, I., and Fuentes, J. D.: Denuder measurements of gas and aerosol species above Arctic snow surfaces at Alert 2000, Atmos. Environ., 36, 5299-5309, 2002.

Ju, X., Liu, X., Zhang, F., and Roelche, M.: Nitrogen fertilization, soil nitrate accumulation, and policy recommendations in several agricultural regions of China, Ambio, 33, 300-305, 2004.

Katsoulis, B. D.: The relationship between synoptic, mesoscale and microscale meteorological parameters during poor air quality events in Athens, Greece, Sci. Total Environ., 181, 13-24, 1996.

Kean, A. J., Harley, R. A., Littlejohn, D., and Kendall, G. R.: Onroad measurement of ammonia and other motor vehicle exhaust emissions, Environ. Sci. Technol., 34, 3535-3539, 2000.

Kirchner, M., Braeutigam, S., Feicht, E., and Löflund, M.: Ammonia emissions from vehicles and the effects on ambient air concentrations, Fresen. Environ. Bull., 11, 454-458, 2002.

Klimont, Z.: Current and Future emissions of Ammonia in China, 10th International Emission Inventory Conference: One Atmosphere, One Inventory, Many Challenges, US EPA, 1-3 May, Denver, USA, available at: http://www.epa.gov/ttn/chief/ conference/ei10/ammonia/klimont.pdf, 2001.

Krupa, S. V.: Effects of atmospheric ammonia $\left(\mathrm{NH}_{3}\right)$ on terrestrial vegetation: A review, Environ. Pollut., 124, 179-221. 2003.

Langford, A. O. and Fehsenfeld, F. C.: The role of natural vegetation as a source or sink for atmospheric ammonia: a case study, Science, 255, 581-583, 1992.

Langford, A. O., Fehsenfeld, F. C., Zachariassen, J., and Schimel, D. S.: Gaseous ammonia fluxes and background concentrations in terrestrial ecosystems of the United States, Global Biogeochem. Cy., 6, 459-483, 1992.

Lee, D. S., Dollard, G. J., Derwent, R. G., and Pepler, S.: Observations on gaseous and aerosols components of atmosphere and their relationships, Water Air Soil Poll., 113, 175-202, 1999.

Lee, H. S., Kang, C. M., Kang, B. W., and Kim, H. K.: Seasonal variations of acidic air pollutants in Seoul, South Korea, Atmos. Environ., 33, 3143-3152, 1999.

Lee, H., Kim, Y. J., Jung, J., Lee, C., Heue, K.-P., Platt, U., Hu, M., and Zhu, T.: Spatial and temporal variations in $\mathrm{NO}_{2}$ distributions over Beijing, China, measured by imaging differential optical absorption spectroscopy, J. Environ. Manage., 90, 18141823, 2009. 
Lefer, B. L., Talbot, R. W., and Munger, J. W.: Nitric acid and ammonia at a rural northeastern US site, J. Geophys Res., 104, 1645-1661, 1999.

Li, Y., Schwab, J. J., and Demerjian, K. L.: Measurements of ambient ammonia using a tunable diode laser absorption spectrometer: Characteristics of ambient ammonia emissions in an urban area of New York City, J. Geophys. Res., 111(D10), D10S02, doi:10.1029/2005JD006275, 2006.

Meng, Z. Y., Ding, G. A., Xu, X. B., Xu, X. D., Yu, H. Q., and Wang, S. F.: Vertical distributions of $\mathrm{SO}_{2}$ and $\mathrm{NO}_{2}$ in the lower atmosphere in Beijing urban areas, China, Sci. Total Environ., 390, 456-465, 2008.

Meng, Z. Y., Xu, X. B., Yan, P., Ding, G. A., Tang, J., Lin, W. L., Xu, X. D., and Wang, S. F.: Characteristics of trace gaseous pollutants at a regional background station in Northern China, Atmos. Chem. Phys., 9, 927-936, doi:10.5194/acp-9-927-2009, 2009.

Meng, Z. Y., Xu, X. B., Wang, T., Zhang, X.-Y., Yu, X.-L., Wang, S.-F., Lin, W.-L., Chen, Y.-Z., Jiang, Y.-A., and An, X.-Q.: Ambient sulphur dioxide, nitrogen dioxide, and ammonia at ten background and rural sites in China during 2007-2008, Atmos. Environ., 44, 2625-2631, 2010.

Olivier, J. G. J., Bouwman, A. F., Van der Hoek, K. W., and Berdowski, J. J. M.: Global air emission inventories for anthropogenic sources of $\mathrm{NO}_{\mathrm{x}}, \mathrm{NH}_{3}$, and $\mathrm{N}_{2} \mathrm{O}$ in 1990, Environ. Pollut., 102, 135-148, 1998.

Olszyna, K. J., Bairai, S. T., and Tanner, R. L.: Effect of ambient $\mathrm{NH}_{3}$ levels on $\mathrm{PM}_{2.5}$ composition in the Great Smoky Mountains National Park, Atmos. Environ., 39, 4593-4606, 2005.

Perrino, C., De Santis, F., and Febo, A.: Criteria for the choice of a denuder sampling technique devoted to the measurement of atmospheric nitrous and nitric acids, Atmos. Environ., 24A, 617626, 1990.

Perrino, C. and Gherardi, M.: Optimization of the coating layer for the measurement of ammonia by diffusion denuders, Atmos. Environ., 33, 4579-4587, 1999.

Perrino, C., Ramirez, D., and Allegrini, I.: Monitoring acidic air pollutants near Rome by means of diffusion lines: development of a specific quality control procedure, Atmos. Environ., 35, 331-341, 2001a.

Perrino, C., Pietrodangelo, A., and Febo, A.: An atmospheric stability index based on radon progeny measurements for the evaluation of primary urban pollution, Atmos. Environ., 35, 52355244, 2001b.

Perrino, C., Catrambone, M., Di Menno Di Bucchianico, A., and Allegrini, I.: Gaseous ammonia in the urban area of Rome, Italy, and its relationship with traffic emissions, Atmos. Environ., 36, 5385-5394, 2002.

Possanzini, M., Febo, A., and Liberti, A.: New design of a high performance denuder for the sampling of atmospheric pollutants, Atmos. Environ., 17, 2605-2610, 1983.

Possanzini, M., De Santis, F., and Di Palo, V.: Measurements of nitric acid and ammonium salts in lower Bavaria, Atmos. Environ., 33, 3597-3602, 1999.

Pryor, S. C., Barthelmie, R. J., Sørensen, L. L., and Jensen, B.: Ammonia concentrations and fluxes over a forest in the midwestern USA, Atmos. Environ., 35, 5645-5656, 2001.

Reis, S., Pinder, R. W., Zhang, M., Lijie, G., and Sutton, M. A.: Reactive nitrogen in atmospheric emission inventories, At- mos. Chem. Phys., 9, 7657-7677, doi:10.5194/acp-9-7657-2009, 2009.

Robarge, W. P., Walker, J. T., McCulloch, R. B., and Murray, G.: Atmospheric concentrations of ammonia and ammonium at an agricultural site in the southeast United States, Atmos. Environ., 36, 1661-1674, 2002.

Roelle, P. A. and Aneja, V. P.: Characterization of ammonia emissions from soils in the upper coastal plain, North Carolina, Atmos. Environ., 36, 1087-1097, 2002.

Shen, J. L., Tang, A. H., Liu, X. J., Fangmeier, A., Goulding, K. T. W., and Zhang, F. S.: High concentrations and dry deposition of reactive nitrogen species at two sites in the North China Plain, Environ. Pollut., 157, 3106-3113, 2009.

Singh, S. P., Satsangi, G. S., Khare, P., Lakhani, A., Maharaj Kumari, K., and Srivastava, S. S.: Multiphase measurement of atmospheric ammonia, Chemosphere - Global Change Science, 3, 107-116, 2001.

Streets, D. G., Bond, T. C., Carmichael, G. R., Fernandes, S. D., Fu, Q., He, D., Klimont, Z., Nelson, S. M., Tsai, N. Y., Wang, M. Q., Woo, J. H., and Yarber, K. F.: An inventory of gaseous and primary aerosol emissions in Asia in the year 2000, J. Geophys Res., 108(D21), 8809, doi:10.1029/2002JD003093, 2003.

Streets, D. G., Fu, J. S., Jang, C. J., Hao, J., He, K., Tang, X., Zhang, Y., Wang, Z., Li, Z., Zhang, Q., Wang, L., Wang, B., and Yu, C.: Air quality during the 2008 Beijing Olympic Games, Atmos. Environ., 41, 480-492, 2007.

Sutton, M. A., Pitcairn, C. E. R., and Fowler, D.: The exchange of ammonia between the atmosphere and plant communities, Adv. Ecol. Res., 24, 301-393, 1993.

Sutton, M. A., Asman, W. A. H., and Schjørring, J. K.: Dry deposition of reduced nitrogen, Tellus, 46B, 255-273, 1994.

Sutton, M. A., Place, C. J., Eager, M., Fowler, D., and Smith, R. L.: Assessment of the magnitude of ammonia emissions in the United Kingdom, Atmos. Environ., 29, 1393-1411, 1995.

Sutton, M. A., Dragosits, U., Tang, Y. S., and Fowler, D.: Ammonia emissions from non-agricultural sources in the UK, Atmos. Environ., 34, 855-869, 2000.

Trebs, I., Meixner, F. X., Slanina, J., Otjes, R., Jongejan, P., and Andreae, M. O.: Real-time measurements of ammonia, acidic trace gases and water-soluble inorganic aerosol species at a rural site in the Amazon Basin, Atmos. Chem. Phys., 4, 967-987, doi:10.5194/acp-4-967-2004, 2004.

Trebs, I., Metzger, S., Meixner, F. X., Helas, G. N., Hoffer, A., Rudich, Y., Falkovich, A. H., Moura, M. A. L., da Silva, R. S., Artaxo, P., Slanina, J., and Andreae, M. O.: The $\mathrm{NH}_{4}^{+}-\mathrm{NO}_{3}^{-}-$ $\mathrm{Cl}^{-}-\mathrm{SO}_{4}^{2-}-\mathrm{H}_{2} \mathrm{O}$ aerosol system and its gas phase precursors at a pasture site in the Amazon Basin: How relevant are mineral cations and soluble organic acids?, J. Geophys. Res.-Atmos., 110(D7), D07303, doi:10.1029/2004JD005478, 2005.

USEPA: National Emission Inventory Tier Summaries: http://www. epa.gov/ttn/chief/eiinformation.html, access: 14 August 2009.

Vogt, E., Held, A., and Klemm, O.: Sources and concentrations of gaseous and particulate reduced nitrogen in the city of Münster (Germany), Atmos. Environ., 39, 7393-7402, 2005.

Walker, J. T., Whitall, D. R., Robarge, W., and Paerl, H. W.: Ambient ammonia and ammonium aerosol across a region of variable ammonia emission density, Atmos. Environ., 38, 1235-1246, 2004.

Wang, X., Mauzerall, D. L., Hu, Y., Russell, A. G., Larson, E. D., 
Woo, J.-H., Streets, D. G., and Guenther, A.: A high-resolution emission inventory for eastern China in 2000 and three scenarios for 2020, Atmos. Environ., 39, 5917-5933, 2005.

Wang, H., Fu, L., Lin, X., Zhou, Y., and Chen, J.: A bottom-up methodology to estimate vehicle emissions for the Beijing urban area, Sci. Total Environ., 407, 1947-1953, 2009.

Wang, B., Shao, M., Lu, S. H., Yuan, B., Zhao, Y., Wang, M., Zhang, S. Q., and Wu, D.: Variation of ambient non-methane hydrocarbons in Beijing city in summer 2008, Atmos. Chem. Phys., 10, 5911-5923, doi:10.5194/acp-10-5911-2010, 2010.

Wang, H., Fu, L., Lin, X., Zhou, Y., Du, X., and Ge, W.: Trends in vehicular emissions in China's mega cities from 1995 to 2005 , Environ. Pollut., 158, 394-400, 2010.

Whitehead, J. D., Longley, I. D., and Gallagher, M. W.: Seasonal and diurnal variation in atmospheric ammonia in an urban environment measured using a quantum cascade laser absorption spectrometer, Water Air Soil Poll., 183, 317-329, 2007.

Xia, X., Chen, H., and Zhang, W.: Analysis of the dependence of column-integrated aerosol properties on long-range transport of air masses in Beijing, Atmos. Environ., 41, 7739-7750, 2007.

Yamamoto, N., Kabeya, N., Onodera, M., Takahahi, S., Komori, Y., and Nakazuka, E.: Seasonal variation of atmospheric ammonia and particulate ammonium concentrations in the urban atmosphere of Yokohama over a 5-year period, Atmos. Environ., 22, 2621-2623, 1988.
Yamamoto, N., Nishiura, H., Honjo, T., Ishikawa, Y., and Suzuki, K.: A long-term study of atmospheric ammonia and particulate ammonium concentrations in Yokohama, Japan, Atmos. Environ., 29, 97-103, 1995.

Yao, X., Lau, A. P. S., Fang, M., Chan, C. K., and Hu, M.: Size distributions and formation of ionic species in atmospheric particulate pollutants in Beijing, China: 1-inorganic ions, Atmos. Environ., 37, 2991-3000, 2003.

Zhang, Y., Dore, A. J., Ma, L., Liu, X. J., Ma, W. Q., Cape, J. N., and Zhang, F. S.: Agricultural ammonia emissions inventory and spatial distribution in the North China Plain, Environ. Pollut., 158, 490-501, 2010.

Zhao, D. and Wang, A.: Estimation of anthropogenic ammonia emissions in Asia, Atmos. Environ., 28, 687-694, 1994.

Zheng, M., Salmon, L. G., Schauer, J. J., Zeng, L., Kiang, C. S., Zhang, Y., and Cass, G. R.: Seasonal trends in $\mathrm{PM}_{2.5}$ source contributions in Beijing, China, Atmos. Environ., 39, 3967-3976, 2005 . 